\title{
Millennial-scale variability of East Asian summer monsoon inferred from sea surface salinity in the northern East China Sea (ECS) and its impact on the Japan Sea during Marine Isotope Stage (MIS) 3
}

\author{
Yoshimi Kubota ${ }^{1 *}$, Katsunori Kimoto ${ }^{2}$, Ryuji Tada $^{3}$, Masao Uchida ${ }^{4}$ and Ken Ikehara ${ }^{5}$
}

\begin{abstract}
Color alternations in deep-sea sediment in the Japan Sea have been thought to be linked to millennial-scale variations in the East Asian summer monsoon (EASM), associated with the Dansgaard-Oeschger (D-O) cycles and Heinrich events in the high-latitude North Atlantic during Marine Isotope Stage 3 (MIS 3). In this study, we investigate the variability of sea surface salinity (SSS) in the northern East China Sea (ECS) to evaluate the EASM precipitation in South China and its linkage to the sediment color of the Japan Sea during MIS 3. High time resolution (<100 years) SSS along with sea surface temperature (SST) records were reconstructed using paired $\mathrm{Mg} / \mathrm{Ca}$ and the oxygen isotope of planktic foraminifera Globigerionoides ruber sensu stricto from core KR07-12 PC-01 recovered from the northern ECS. The results indicate that millennial-scale variability of the SSS is observed with the amplitude of $\sim \pm 1$ during MIS 3. The variations in SSS are well correlated to D-O cycles and Heinrichs. The EASM precipitation decreases in association with the southward shift of the westerly jet in D-O stadials and Heinrichs, suggesting suppressed moisture convergence along the EASM front associated with weakened North Pacific subtropical high in response to the slow-down of the Atlantic Meridional Overturning Circulation. In a comparison between the SSS in the ECS and the color alternation in the Japan Sea, closely correlated variations between the two records in the interval 44-34 ka indicate that the SSS in the ECS plays a crucial role in regulating nutrient and salinity inflow into the Japan Sea. However, the linkage becomes ambiguous, especially after $\sim 30 \mathrm{ka}$, when the sea level falls toward the level of the last glacial maximum. This shift is associated with changes in sediment facies, confirming that the underlying mechanism in regulating the sedimentary change in the Japan Sea depends on the sea level.
\end{abstract}

Keywords: East Asian summer monsoon, Salinity, East China Sea, MIS 3, Mg/Ca-derived SST, D-O cycles

\section{Background}

Since high-resolution, continuous oxygen isotope $\left(\delta^{18} \mathrm{O}\right)$ records of the Greenland ice cores covering the past > $100 \mathrm{ka}$ have demonstrated millennial-scale climate changes during Marine Isotope Stage (MIS) 3 (59-29 $\mathrm{ka})$, the so-called Dansgaard-Oeschger (D-O) cycle. The $\mathrm{D}-\mathrm{O}$ cycle attracted considerable attention due to its

\footnotetext{
* Correspondence: yoshimi@kahaku.go.jp

${ }^{1}$ Department of Geology and Paleontology, National Museum of Nature and Science, 4-1-1, Amakubo, Tsukuba, Ibaraki 305-0005, Japan

Full list of author information is available at the end of the article
}

abruptness, large amplitude, high frequency, and potential impact on global climate (e.g., Dansgaard et al. 1993). In the Asian monsoon region, the Quaternary hemipelagic sediments of the Japan Sea are characterized by centimeter- to decimeter-scale alternation of dark and light clay to silty clay, which are bio-siliceous and/or bio-calcareous to a various degree (Tada et al. 1999; Tada et al. 2018; Irino et al. 2018). Tada et al. (1999) demonstrated the occurrence of the basin-wide dark-light color alternations in the sediments of the Japan Sea, which are well correlated with D-O cycles. 
They hypothesized that these sediment color alternations could be attributed to changes in the nutrient and freshwater influx through the Tsushima Strait due to changes in the Changjiang (Yangtze) River discharge (i.e., summer precipitation in South China). Namely, increased summer precipitation in the Changjiang Basin caused the expansion of the low-salinity and nutrientenriched coastal waters in the northern part of the East China Sea (ECS) during the interstadials of the D-O cycle, which flowed into the Japan Sea and resulted in the accumulation of organic carbon-rich dark layers (Tada et al. 1999).

Summer precipitation in East Asia is known as Meiyu (China), Baiu (Japan), and Changma (Korea), and is one of the crucial aspects of the East Asian summer monsoon (EASM) system. A series of high-resolution speleothem $\delta^{18} \mathrm{O}\left(\delta^{18} \mathrm{O}_{\mathrm{sp}}\right)$ records in southeastern and central China, which had been interpreted as reflecting EASM intensity/precipitation, demonstrated millennial-scale variations in association with $\mathrm{D}-\mathrm{O}$ cycles (Wang et al. 2001; Cheng et al. 2016). However, the interpretation of the $\delta^{18} \mathrm{O}_{\text {sp }}$ is controversial as studies using analyses of $\delta^{18} \mathrm{O}$ mass balance and climate models suggested that the $\delta^{18} \mathrm{O}_{\text {sp }}$ record reflects neither local precipitation nor EASM circulation intensity, but rather changes in the moisture source or seasonality of the precipitation (Clemens et al. 2010; Dayem et al. 2010; Pausata et al. 2011; Maher and Thompson 2012). More recently, a trace element study on one of the Chinese speleothems has claimed that millennial-scale $\delta^{18} \mathrm{O}_{\mathrm{sp}}$ variations during the last deglaciation were better interpreted as changes in the EASM circulation, instead of the local precipitation (Zhang et al. 2018). By contrast, a proxy of sea surface salinity (SSS) from a marine core provides reliable information on the changes in regional precipitation, through a freshwater inflow from rivers, which can further serve to test the hypothesis by Tada et al. (1999).

The northern ECS is a crucial area, vis-à-vis its position where the freshwater from the Changjiang (Yangtze) River reaches it and the waters from the ECS inflow to the Japan Sea (Fig. 1). Ijiri et al. (2005) reported millennial-scale light $\delta^{18} \mathrm{O}$ peaks of planktic foraminifera Globigerinoides ruber sensu stricto $\left(\delta^{18} \mathrm{O}_{\mathrm{p}}\right)$ in the northern ECS during Marine Isotope Stage (MIS) 3 and stated that these peaks might capture larger freshwater discharge events associated with D-O interstadials. However, their age model did not allow for determination of these timings precisely enough compared to other records, and the effect of temperature changes on foraminiferal $\delta^{18} \mathrm{O}$ was not adequately evaluated because they used an alkenone temperature proxy, which may have been recording sea surface temperature (SST) during a different season and at different depth from those of G. ruber s.s. (Kim et al. 2015).

Thus, in this study, we reconstructed the local $\delta^{18} \mathrm{O}$ of seawater $\left(\delta^{18} \mathrm{O}_{\mathrm{w} \text {-local }}\right)$, an indicator of SSS, and SST in the northern ECS during MIS 3 using paired $\delta^{18} \mathrm{O}_{\mathrm{p}}$ and $\mathrm{Mg} / \mathrm{Ca}$ of G. ruber s.s., and estimated variability of SSS to test the presence of millennial-scale EASM precipitation oscillations in South China associated with D-O cycles. We used a marine core KR07-12 PC-01 recovered from the northern ECS that covers the time interval since $44 \mathrm{ka}$, thus covering the late half of MIS 3.

The ECS is a marginal sea in the northwestern Pacific Ocean, and the East Asian monsoons control its seasonal ocean current system (e.g., Ichikawa and Beardsley 2002). The SSS in the ECS changes drastically throughout a year, particularly in the northern part, due to the considerable influence of river discharge caused by the EASM precipitation (Ichikawa and Beardsley 2002). The Changiiang River is the most significant contributor of freshwater to the ECS, accounting for $\sim 90 \%$ of the total freshwater supplied to the ECS from rivers, and its discharge is characterized by a remarkable seasonal cycle with its zenith in July and nadir in January (Chen et al. 1994; Isobe et al. 2002). Accordingly, the SSS in the northern ECS decreases in summer and increases in winter (Ichikawa and Beardsley 2002). Changjiang Diluted Water (CDW) is formed by Changiiang freshwater mixing with the ambient seawater around the estuary, which then flows eastward into the Japan Sea during the summer (e.g., Ichikawa and Beardsley 2002; Isobe et al. 2002).

Based on instrumental observations, the maximum SST near the studied site is $28.4{ }^{\circ} \mathrm{C}$ in August, and the minimum is $17.7^{\circ} \mathrm{C}$ in February (Japan Oceanographic Data Center 2004). In contrast, SSS reaches a maximum of 34.7 in February and decreases to a minimum of 33.0 in July, when the maximum discharge from the Changjiang River occurs. The spatial patterns of SST and SSS during summer are characterized by lower SST and SSS in the northwest and higher SST and SSS in the southeast part of the northern ECS (Fig. 1). The lower SSS during the summer suggests that river discharge due to the EASM dominates the seasonal changes in the Kuroshio (Sun et al. 2005); otherwise, the strengthened Kuroshio results in increased SSS during summer, when its volume transport is the largest (Ichikawa and Beardsley 1993; Andres et al. 2008). It was demonstrated that the CDW reaches the easternmost part of the northern ECS across the shelf break during summer, based on ${ }^{226} \mathrm{Ra}$ and ${ }^{228} \mathrm{Ra}$ measurements of surface waters (Inoue et al. 2012). Inoue et al. (2012) calculated the relative contribution of the Changjiang freshwater in this area as approximately $2-3 \%$ in July and October, based on mass balance calculation of the SSS and ${ }^{228} \mathrm{Ra}$ concentration 


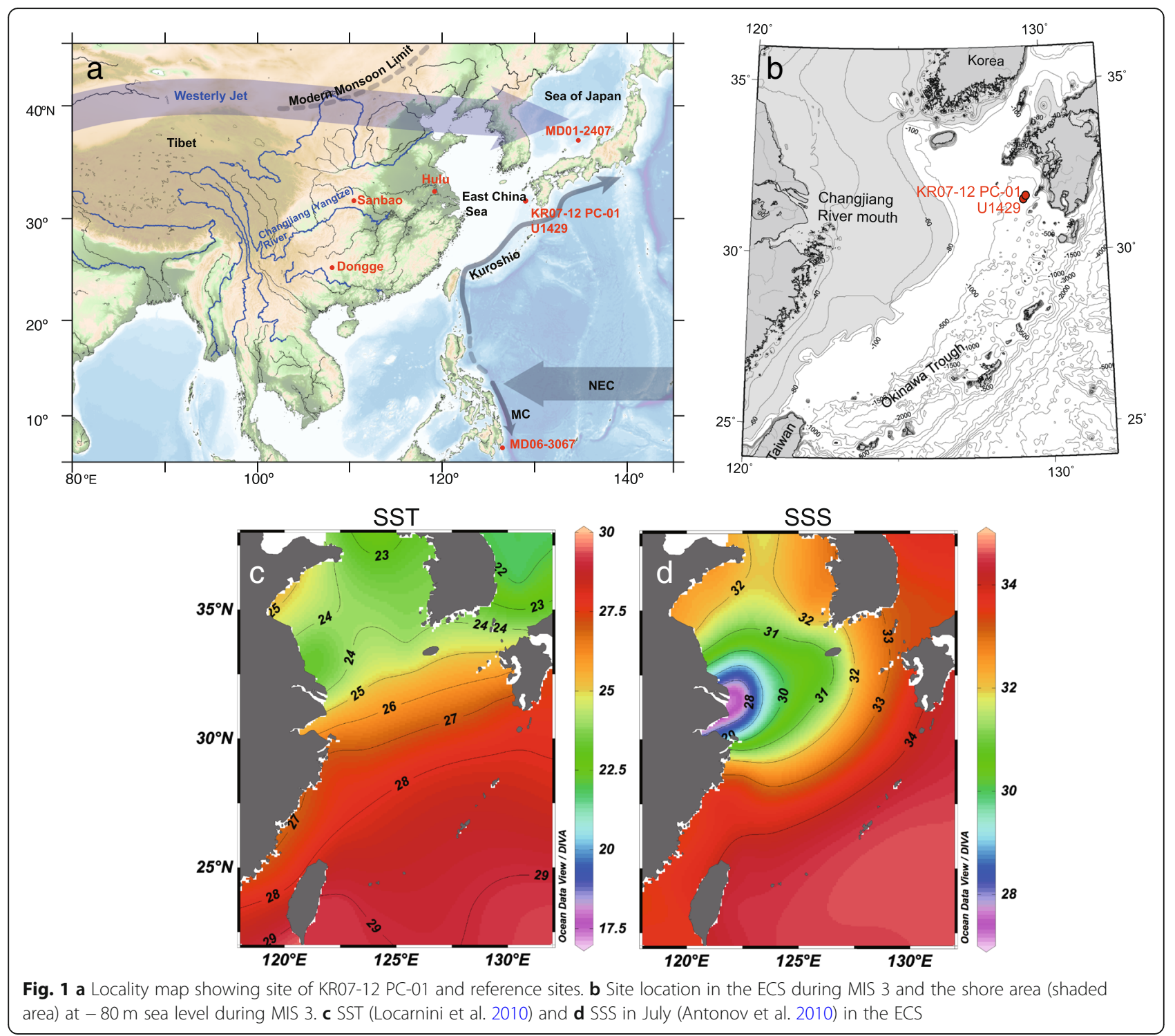

of surface water samples collected between 2008 and 2010. Instrumental SSS data around the core site shows a negative correlation with the Changjiang River discharge during the wet season for the past 50 years (Kubota et al. 2015), confirming that the studied site is an appropriate location to reconstruct SSS.

\section{Methods/Experimental}

The piston core KR07-12 PC-01 $\left(31^{\circ} 40.63^{\prime} \mathrm{N}, 129^{\circ}\right.$ $01.98^{\prime}$ E, $736 \mathrm{~m}$ water depth) was composed of olive-black or olive-gray, homogenous, well-bioturbated clay. Scattered shell fragments and mottled textures caused by burrows were occasionally identified (Fig. 2). Ash layers were identified at depth intervals of 98.0$118.0 \mathrm{~cm}$ and $947.5-990.3 \mathrm{~cm}$, which correspond to the K-Ah and Aira (AT) tephras, respectively, based on the morphology and refractive index of glass shards in each tephra, and heavy mineral assemblages (Table 1). An ash pocket was found at $170.0-172.0 \mathrm{~cm}$, identified as Sz-S (Table 1). The refractive index of each volcanic glass shard was measured using the RIMS-2002 analyzer (Danhara et al. 1992) at Kyoto Fission Track Co. Ltd. The other ashes found at 75.0-84.0 cm and 188.0-190.0 $\mathrm{cm}$ are unknown.

Approximately $10 \mathrm{~cm}^{3}$ of bulk sediment samples was subsampled at $2.5 \mathrm{~cm}$ intervals and washed using a $63 \mu \mathrm{m}$ mesh to concentrate foraminiferal tests for ${ }^{14} \mathrm{C}$ dating, $\delta^{18} \mathrm{O}_{\mathrm{p}}$, and $\mathrm{Mg} / \mathrm{Ca}$ measurements. For ${ }^{14} \mathrm{C}$ dating, approximately $3-5 \mathrm{mg}$ of the planktic foraminifera Neogloboquadrina dutertrei, from the size fraction $>250 \mu \mathrm{m}$, was collected from 15 horizons (Table 2). All of the ${ }^{14} \mathrm{C}$ data were acquired at the NIES-TERRA AMS facility, National Institute for Environmental Studies (Tanaka et al. 2000; Yoneda et al. 2004; Uchida et al. 


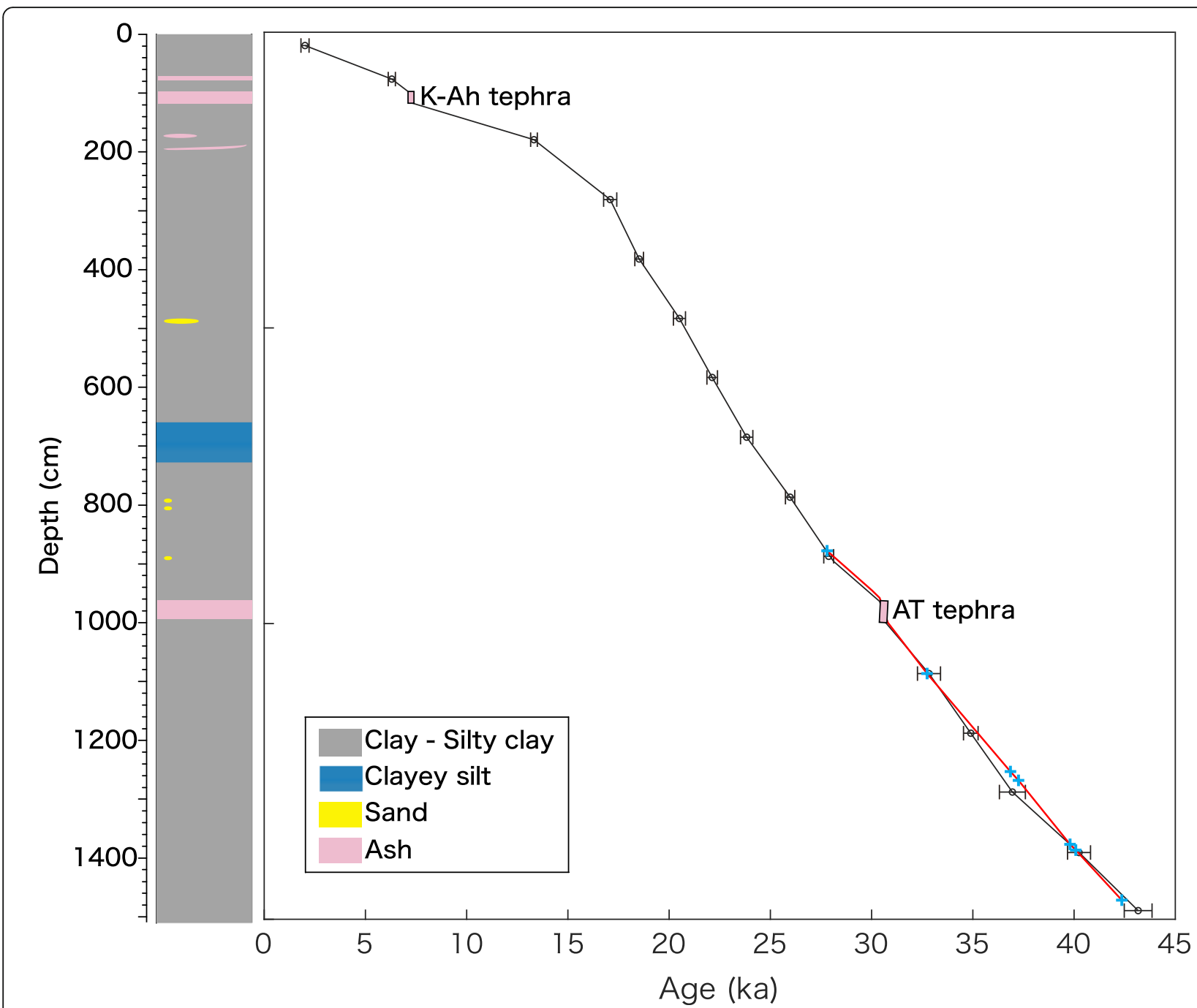

Fig. 2 Age-depth relationship of core KR07-12 PC-01 together with $2 \sigma$ age uncertainties and columnar section. The black circles and lines represent ${ }^{14} \mathrm{C}$-based datum and its age model. The red line indicates the fine-tuned age model. The blue crosses represent the tie points in the finetuned age model

2004). We analyzed 244 samples in total for paired $\delta^{18} \mathrm{O}_{\mathrm{p}}$ and $\mathrm{Mg} / \mathrm{Ca}$. The time resolution of the analyses was $\sim 80$ years for MIS 3, 130 years for early MIS 2 and Last Glacial Maximum (LGM), and $>300$ years for the last deglaciation. For $\delta^{18} \mathrm{O}_{\mathrm{p}}$ and trace element analyses, approximately 30-40 individual G. ruber s.s. was picked from 250 to $355 \mu \mathrm{m}$ size fractions and crushed to homogenize. After being cleaned by milli-Q water and methanol, approximately $50-70 \mu \mathrm{g}$ of foraminiferal tests was separated and used for the oxygen isotope analysis. The $\delta^{18} \mathrm{O}_{\mathrm{p}}$ was measured by two Finnigan MAT 252 Stable Isotope Ratio Mass Spectrometers with a Keil III carbonate device installed at the Mutsu Institute for Oceanography in the Japan Agency for Marine-Earth Science and Technology and at the University of Tokyo. The reproducibility of the measurement was better than $\pm 0.05 \%$ o $(1 \sigma)$ for $\delta^{18} \mathrm{O}_{\mathrm{p}}$, as determined by replicate measurements of international standards NBS-19 (RM8544 Limestone) and JCp-1 (Coral Porites sp.), provided by the Geological Survey of Japan (GSJ/AIST).

Additional cleaning steps were performed for trace element analyses. The samples were cleaned using the reductive method, including reductive and oxidative cleaning steps published by Boyle and Keigwin (1985), with a slight modification (Kubota et al. 2010). $\mathrm{Mg} / \mathrm{Ca}$ analysis was performed using a Thermo Finnigan ELEMENT 2 High-Resolution Multi-Sector Inductively Coupled Plasma Mass Spectrometer (HR-ICP-MS) at the Mutsu Institute for Oceanography in the Japan Agency for Marine-Earth Science and Technology. Isotopes of four elements $\left({ }^{24} \mathrm{Mg}\right.$, ${ }^{44} \mathrm{Ca},{ }^{48} \mathrm{Ca}$, and ${ }^{55} \mathrm{Mn}$ ) were analyzed using $\mathrm{Sc}$ as an internal standard (Uchida et al. 2008). Four working standards were prepared by successive dilutions of the stock standard solutions to match the concentrations of $\mathrm{Ca}$ 
Table 1 Results of tephra analyses

\begin{tabular}{|c|c|c|c|c|c|c|c|c|c|}
\hline \multirow[t]{2}{*}{ Sample ID } & \multirow{2}{*}{$\begin{array}{l}\text { Sub-bottom } \\
\text { depth }(\mathrm{cm})\end{array}$} & \multirow[t]{2}{*}{ Glass type } & \multirow[t]{2}{*}{ Heavy minerals } & \multirow{2}{*}{$\begin{array}{l}\text { Glass } \\
\text { morphology }\end{array}$} & \multicolumn{4}{|c|}{ Refractive Index of glass shard } & \multirow[t]{2}{*}{ Correlation } \\
\hline & & & & & Maximum & Minimum & Mean & Mode & \\
\hline KRP10650 & $98-118$ & $b w>>p m$ & Opx, Opq, Cpx & $\mathrm{H}>\mathrm{T}, \mathrm{C}$ & 1.5102 & 1.5198 & 1.5123 & 1.511 & K-Ah \\
\hline KRP10711 & $170-172$ & $\mathrm{pm}$ & Opx, Cpx, Opq (Ap, GHb) & $\mathrm{T}, \mathrm{C}, \mathrm{H}$ & 1.5067 & 1.5102 & 1.509 & 1.509 & $\mathrm{~S}-\mathrm{Sz}$ \\
\hline KRP11507 & $947.5-990.3$ & $\mathrm{bw}>>\mathrm{pm}$ & Opx, GHb, Ap, Cpx, Bt & $\mathrm{H}>\mathrm{T}, \mathrm{C}$ & 1.4982 & 1.5011 & 1.5001 & 1.5 & AT \\
\hline
\end{tabular}

Glass type: $b w$ bubble-wall type, $p m$ pumice type. Heavy minerals: Opx orthopyroxene, $C p x$ clinopyroxene, GHb green hornblende, Opq opaque minerals, $B t$ biotite, At apatite. Glass morphology (after Yoshikawa 1976): $H$ large broken bubble-wall type, $T$ fibrous and pumice type, $C$ intermediate type

(approximately $100 \mathrm{ppb}, 500 \mathrm{ppb}, 2 \mathrm{ppm}$, and $5 \mathrm{ppm}$ ) and $\mathrm{Mg}(0.05 \mathrm{ppb}, 0.2 \mathrm{ppb}, 1.0 \mathrm{ppb}$, and $5 \mathrm{ppb})$, respectively, which covered the $\mathrm{Ca}$ and $\mathrm{Mg}$ concentration ranges of all samples (Kubota et al. 2010, 2015). The precision of the replicate analysis of the working standard for $\mathrm{Mg} / \mathrm{Ca}$ was better than $\pm 0.09 \mathrm{mmol} / \mathrm{mol}$, corresponding to $\pm 0.3^{\circ} \mathrm{C}$ in temperature scale. $\mathrm{Mn} / \mathrm{Ca}$ was analyzed to monitor $\mathrm{Mn}-\mathrm{Fe}$ oxide contamination. Mn/Ca was under $200 \mu \mathrm{mol} /$ mol in most of the samples (Additional file 1: Figure S1), but exceeded $400 \mu \mathrm{mol} / \mathrm{mol}$ in 5 samples. However, these values are not excluded because there is no correlation between $\mathrm{Mg} / \mathrm{Ca}$ and $\mathrm{Mn} / \mathrm{Ca}$ (Additional file 1: Figure S1). In order to examine the homogeneity of the sample, G. ruber s.s. were repicked from 66 randomly selected horizons of core KR07-12 PC-01 and run for $\mathrm{Mg} / \mathrm{Ca}$ analyses with the same cleaning protocol. The reanalyzed $\mathrm{Mg} / \mathrm{Ca}$ value at $1392.1-1389.6 \mathrm{~cm}$ was $5.0^{\circ} \mathrm{C}$ lower than the first one and was discarded. An average of the differences in $\mathrm{Mg} / \mathrm{Ca}$ values of the replicate analyses for the rest of 65 horizons was $0.16 \mathrm{mmol} / \mathrm{mol}\left(\sim 0.7^{\circ} \mathrm{C}\right)$. Compared with the $\mathrm{Mg} / \mathrm{Ca}$ values of U1429 for the same period in the previous study (Clemens et al. 2018), an average of KR07-12 PC-01 was slightly lower by $0.157 \mathrm{mmol} / \mathrm{mol}$ than those of U1429.

Table 2 Results of AMS radiocarbon and calendar ages

\begin{tabular}{llll}
\hline Depth $(\mathrm{cm})$ & $\begin{array}{l}{ }^{14} \mathrm{C} \text { age } \\
\text { (year BP) }\end{array}$ & ${ }^{14} \mathrm{C}$ age error & $\begin{array}{l}2 \sigma \text { calibrated calendar } \\
\text { ages (year BP) }\end{array}$ \\
\hline $20-25$ & 2283 & 33 & $1815-2215$ \\
$78-80.5$ & 5790 & 42 & $6125-6479$ \\
$180.5-183$ & 11,769 & 48 & $13,159-13,489$ \\
$280.5-285.5$ & 14,373 & 55 & $16,764-17,414$ \\
$381-386$ & 15,566 & 59 & $18,307-18,733$ \\
$481.5-486.5$ & 17,323 & 75 & $20,210-20,808$ \\
$581.3-586.3$ & 18,581 & 78 & $21,865-22,389$ \\
$682.3-687.3$ & 20,114 & 88 & $23,525-24,134$ \\
$785-787.5$ & 22,039 & 103 & $25,746-26,202$ \\
$885-887.5$ & 24,175 & 98 & $27,637-28,125$ \\
$1083.3-1085.8$ & 29,033 & 132 & $32,265-33,404$ \\
$1184.1-1186.6$ & 31,295 & 152 & $34,538-35,259$ \\
$1283.6-1286.1$ & 33,168 & 166 & $36,311-37,596$ \\
$1384.6-1389.6$ & 35,930 & 204 & $39,677-40,813$ \\
$1484.1-1486.6$ & 39,650 & 408 & $42,479-43,851$ \\
\hline
\end{tabular}

Since the $\mathrm{Mg} / \mathrm{Ca}$ values of U1429 were confirmed by an international $\mathrm{CaCO}_{3}$ reference standard, coral Porites standard material JCp-1 $(4.199 \pm 0.065 \mathrm{mmol} / \mathrm{mol}$, Hathorne et al. 2013), we added $0.157 \mathrm{mmol} / \mathrm{mol}\left(\sim 0.6^{\circ} \mathrm{C}\right)$ to the original $\mathrm{Mg} / \mathrm{Ca}$ values of KR07-12 PC-01 to adjust to the value of the U1429.

Although $\mathrm{Mg} / \mathrm{Ca}$ of foraminiferal calcite is primarily controlled by temperature, a secondary effect of the salinity has been pointed out; $\mathrm{Mg} / \mathrm{Ca}$ increases when salinity increases (e.g., Lea et al. 1999). In this study, in order to examine the salinity effect on the results to better estimate the SSS variability in the northern ECS, we tested three calibration methods to obtain SST and $\delta^{18} \mathrm{O}_{\mathrm{w} \text {-local }}$ as follows: (1) a conventional $\mathrm{Mg} / \mathrm{Ca}$ calibration without salinity correction (referred to "no salinity correction"), (2) an $\mathrm{Mg} / \mathrm{Ca}$ calibration with salinity correction ("salinity correction"), (3) an $\mathrm{Mg} / \mathrm{Ca}$ calibration with salinity correction in addition to incorporating the effect of changes in endmember $\delta^{18} \mathrm{O}_{\mathrm{w}}$ ("endmember correction"). The SSS is reconstructed in the methods of "salinity correction" and "endmember correction." Here, we refer to "endmember" as physical values such as SSS and $\delta^{18} \mathrm{O}_{\mathrm{w}}$ in the source regions. The purpose of the "endmember correction" is to examine whether or not changes in the $\delta^{18} \mathrm{O}_{\mathrm{w}}$ in the source region account for changes in the $\delta^{18} \mathrm{O}_{\mathrm{w}}$ in the northern ECS. The results are compared in Fig. 3.

First, for the "no salinity correction" calculation, we used an $\mathrm{Mg} / \mathrm{Ca}$ calibration (Eq. 1) by Dekens et al. (2002), without correction for sediment water depth, and Bemis et al.'s (1998) $\delta^{18} \mathrm{O}$-temperature relationship (low light) (Eq. 2). The $\delta^{18} \mathrm{O}_{\mathrm{w} \text {-local }}$ was obtained after removing the global sea level effect from total $\delta^{18} \mathrm{O}_{\mathrm{w}}$ using Waelbroeck et al.'s (2002) curve (Eq. 3; Thirumalai et al. 2016).

$$
\begin{aligned}
& \mathrm{Mg} / \mathrm{Ca}=\exp (0.09 \times T) / 0.38 \\
& T=16.5-4.8 \times\left(\delta^{18} \mathrm{O}_{\mathrm{p}}-\delta^{18} \mathrm{O}_{\mathrm{w}}+0.27\right) \\
& \delta^{18} \mathrm{O}_{\mathrm{w}}=\delta^{18} \mathrm{O}_{\mathrm{w}-\text { local }}-0.008 \times \text { sea level }
\end{aligned}
$$

Here, $T, \delta^{18} \mathrm{O}_{\mathrm{p}}$, and $\delta^{18} \mathrm{O}_{\mathrm{w}}$ denote temperature, $\delta^{18} \mathrm{O}$ of planktic foraminiferal calcite, and $\delta^{18} \mathrm{O}$ of water. $\delta^{18} \mathrm{O}_{\mathrm{w}}$ in Eq. 3 includes local and global (sea level) components. Second, for the "salinity correction" calculation, we used an $\mathrm{Mg} / \mathrm{Ca}$ calibration with salinity correction 
(Eq. 4; Tierney et al. 2015) instead of Eq. 1. The SST and $\delta^{18} \mathrm{O}_{\mathrm{w} \text {-local }}$ were derived using a MATLAB script, Paleo-Seawater Uncertainty Solver (PSU Solver) (Thirumalai et al. 2016) with the methodology of Clemens et al. (2018) as explained below. As no regional $\mathrm{Mg} / \mathrm{Ca}$ calibration exists for the ECS, we employed the $\mathrm{Mg} / \mathrm{Ca}$ calibration of Tierney et al. (2015) that utilized all available culture data in a multivariate calibration that accounts for both salinity and temperature. We utilized the $\delta^{18} \mathrm{O}$-temperature relationship of Eq. 2 and the ECS seawater $\delta^{18} \mathrm{O}_{\mathrm{w}-\text { local }}$-salinity relationship of Horikawa et al. (2015) (Eq. 5), as well as the global sea-level curve of Waelbroeck et al. (2002) (Eq. 3).

$$
\begin{aligned}
& \mathrm{Mg} / \mathrm{Ca}=\exp (0.084 \times T+0.051 \times S-2.54) \\
& \delta^{18} \mathrm{O}_{\mathrm{w}-\text { local }}=0.23 \times S-7.74
\end{aligned}
$$

Here, $\mathrm{S}$ represents salinity.

Third, for the "endmember correction" calculation, we replaced Eq. 5 to 6 (LeGrande and Schmidt 2011). This model (Eq. 6) allows slope $(a)$ and intercept (b) to vary through time so that the effect of temporal changes in endmembers is captured. The following two steps were conducted to obtain "a" and "b" in Eq. 6: step 1-estimate of the freshwater $\delta^{18} \mathrm{O}$ to obtain intercept "b," step 2 -estimate of the Kuroshio water $\delta^{18} \mathrm{O}$ and salinity to obtain slope "a." Eventually, errors are given based on the Monte Carlo simulation, as will be explained later in this section. Before the calculation, each data set was linearly interpolated (100-year step).

$$
\delta^{18} \mathrm{O}_{\mathrm{w}}=a \times S+b
$$

In step 1, we regard the freshwater $\delta^{18} \mathrm{O}$ of the Changjiang River as intercept "b" (Kubota et al. 2015). Following Kubota et al. (2015), we utilized a composite record of Cheng et al.'s (2016) $\delta^{18} \mathrm{O}_{\mathrm{sp}}$ to estimate the freshwater $\delta^{18} \mathrm{O}_{\mathrm{w}}$ (Kubota et al. 2015), on the assumption that the temporal variations in $\delta^{18} \mathrm{O}_{\mathrm{sp}}$ reflect the drip water $\delta^{18} \mathrm{O}$ in the caves, hence, the river water $\delta^{18} \mathrm{O}$. We used the total $\delta^{18} \mathrm{O}_{\mathrm{w}}$, which includes local and global components, in Eq. 6 instead of $\delta^{18} \mathrm{O}_{\mathrm{w} \text {-local }}$ to avoid correcting a global component for $\delta^{18} \mathrm{O}_{\mathrm{sp}}$. Here, we define that the variability in intercept "b" is equal to that in $\delta^{18} \mathrm{O}_{\mathrm{sp}}$ (Eq. 7). Both sides of Eq. 7 represent subtracting a modern value from values at a given time in the past. We employed $-7.74 \%$, which is derived from Eq. 5 (Horikawa et al. 2015), as the modern intercept (left side of Eq. 7). For the modern $\delta^{18} \mathrm{O}_{\mathrm{sp}}$ value (right side of Eq. 7), an average for the last $1 \mathrm{ka}$ of the Chinese speleothem record (Cheng et al. 2016) was employed. The time series of the endmember $\delta^{18} \mathrm{O}_{\mathrm{w}}$ is shown in Additional file 2: Figure S2. The adequacy of these parameters will be discussed in the "Results and Discussion" section.

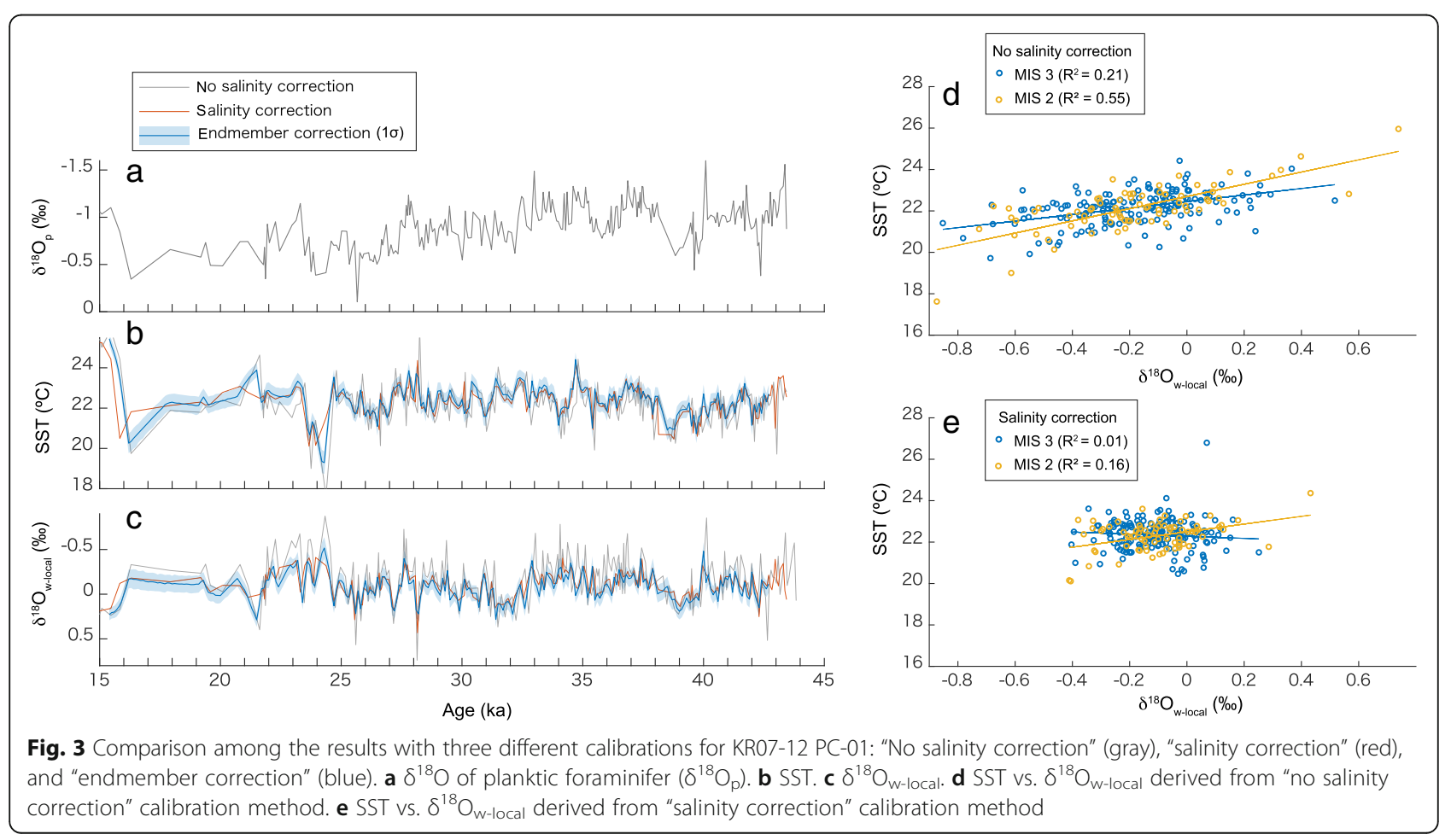




$$
b-(-7.74)=\delta^{18} \mathrm{O}_{\mathrm{sp}}-(-9.0)
$$

In step 2, we obtained another set of $\delta^{18} \mathrm{O}_{\mathrm{w}}$ and $S$ as input data in Eq. 6 to determine slope "a" using a high-time resolution paired $\mathrm{Mg} / \mathrm{Ca}$ and $\delta^{18} \mathrm{O}_{\mathrm{p}}$ data of $\mathrm{G}$. ruber from core MD06-3067 (6 31' N, 126 30' E, 1575 $\mathrm{m}$ water depth) in the western tropical Pacific (Additional file 2: Figure S2; Bolliet et al. 2011). We regard this site as a reference location for the endmember of the Kuroshio water, since the site of core MD06-3067 is affected by the Mindanao Current that shares the same origin of waters, North Equatorial Current, with the Kuroshio. A strong upwelling affects intermediate and subsurface waters in this region, but the upwelled water does not reach the surface upper $75 \mathrm{~m}$ (Udarbe-Walker and Villanoy 2001) where G. ruber dwells. Therefore, it is inferred that surface water in this region still holds the origin's water properties. In fact, the SSS at nearby site MD06-3067 in the western tropical Pacific is 34.0-34.3 during July to September (World Ocean Atlas 2009; Antonov et al. 2010), which is similar to the SSS in the Kuroshio region in the ECS. Although low-resolution $\mathrm{Mg} / \mathrm{Ca}$ and $\delta^{18} \mathrm{O}$ data exists in the north of the bifurcation latitude $\left(\sim 14^{\circ} \mathrm{N}\right)$ of the Kuroshio at Benham Rise (MD06-3047B; Jia et al. 2018), the site MD06-3067 is a better site in terms of the time resolution, as a major process of this "endmember correction" is to evaluate the influence of the millennial-scale variability in the source region. The $\delta^{18} \mathrm{O}_{\mathrm{w}}$ and SSS of core MD06-3067 are derived from PSU Solver with Eqs. 2-4 and $\delta^{18} \mathrm{O}_{\mathrm{w}}$-salinity equation for Palau (Conroy et al. 2017).

In the final step, Eqs. 2-4, 6, and 7 were solved with the input data derived from steps 1 and 2. We performed the Monte Carlo simulation to constrain errors associated with the age uncertainty among the records and temperature, salinity, and $\delta^{18} \mathrm{O}_{\mathrm{w}}$ reconstructions propagated from analytical errors for measurements of $\mathrm{Mg} / \mathrm{Ca}$ and $\delta^{18} \mathrm{O}_{\mathrm{p}}$. In the Monte Carlo simulation, temperature, salinity, and $\delta^{18} \mathrm{O}_{\mathrm{w}}$ at a given time "t" were calculated with randomly selected input data $(\mathrm{Mg} / \mathrm{Ca}$ and $\delta^{18} \mathrm{O}_{\mathrm{p}}$ of KR07-12 PC-01, $\delta^{18} \mathrm{O}_{\mathrm{sp}}$, and $\delta^{18} \mathrm{O}_{\mathrm{w}}$ and salinity of MD06-3067) in the range of $t-0.5 \mathrm{ka}$ $<t<t+0.5 \mathrm{ka}$. The analytical error was prescribed to the $\mathrm{Mg} / \mathrm{Ca}$ and $\delta^{18} \mathrm{O}_{\mathrm{p}}$ data, incorporated as a normal distribution (Thirumalai et al. 2016). We set $0.16 \mathrm{mmol} / \mathrm{mol}$ and $0.05 \%$ for the $\mathrm{Mg} / \mathrm{Ca}$ and $\delta^{18} \mathrm{O}$ uncertainties, respectively. Median value and standard deviation $(1 \sigma)$ are yielded at each time step after 500 repetitions of the simulation (Fig. 3). All of the calculations were performed on MATLAB.

\section{Results and Discussion Age model}

Conventional ${ }^{14} \mathrm{C}$ ages were calibrated to calendar ages using CALIB 7.1 (Stuiver et al. 2016) with Marine13
(Reimer et al. 2013). For the local reservoir correction $(\Delta R),-93 \pm 69$ years, a weighted mean of the 10 nearest locations to the core site (available at http://calib.org/ marine/) was applied. Constant linear sedimentation rates were assumed between two adjacent ${ }^{14} \mathrm{C}$-based age-controlling points (listed in Table 2) when constructing the age model (Fig. 2). In addition to the ${ }^{14} \mathrm{C}$-based datums, published calendar ages of the K-Ah (7.165$7.303 \mathrm{ka})$ and AT $(30.009 \pm 0.189 \mathrm{ka})$ tephras, dated on Lake Suigetsu sediments in SG06 core (Smith et al. 2013), were used as the age datums. In this age model, instantaneous sedimentation was assumed between the top and bottom of the two thick ash layers (K-Ah 98.0$118.0 \mathrm{~cm}$, AT $947.5-990.3 \mathrm{~cm})$. A published ${ }^{14} \mathrm{C}$ age of $\mathrm{S}$-Sz is $11.295 \pm 0.30$ ka derived from soil materials below the tephra layer (Okuno et al. 1997), which was calibrated to a calendar age of $12.631-13.768 \mathrm{ka}(2 \sigma)$ in this study using CALIB 7.1 (Stuiver et al. 2016) with IntCal13 (Reimer et al. 2013). We did not apply the recalibrated age of S-Sz in our model since its uncertainty is large. The S-Sz age with our age model, which is $12.4 \mathrm{ka}$, is younger than the $2 \sigma$ probability range of the soil samples, probably because the soil materials were sampled below the tephra layer (Okuno et al. 1997).

The age model was further fine-tuned to a composite record of the Chinese $\delta^{18} \mathrm{O}_{\mathrm{sp}}$ (Additional file 3: Figure S3 and Additional file 4: Table S1), assuming an in-phase relationship between the climate in the northern ECS and hydroclimate variability over China as mentioned in Clemens et al. (2018). This assumption is justified in the following discussion by correlating the AT tephra layer in our core and its age with others. AT tephra is most precisely dated using the Suigetsu Lake sediment, whose microfossil ${ }^{14} \mathrm{C}$ ages are generally consistent with the IntCal13 curve for a 31-29 ka interval (Reimer et al. 2013). Although the speleothem ${ }^{14} \mathrm{C}$ data from Hulu Cave, China, was available back to $27 \mathrm{ka}$ in 2013, a recently published ${ }^{14} \mathrm{C}$ data set from the same cave confirmed the consistency with IntCal13 between 10 and $33 \mathrm{ka}$ within the uncertainty range of less than \pm $0.5 \mathrm{ka}$ (Cheng et al. 2018 and included figures). Correlating the AT tephra with the speleothem record is possible through IntCal13 without consideration of the marine reservoir, since the ages of our core around 30 ka rely on the age determined by the Suigetsu Lake sediment. We expect that the age uncertainty range of this correlation is probably less than $0.5 \mathrm{ka}$. Compared with the time series of $\delta^{18} \mathrm{O}_{\mathrm{sp}}$, a positive peak in $\delta^{18} \mathrm{O}_{\mathrm{p}}$ in KR07-12 PC-01 at $30 \mathrm{ka}$ is highly likely correlated to a positive peak in $\delta^{18} \mathrm{O}_{\text {sp }}$. This agreement allows us to conclude that this assumption is plausible and further infer that in-phase correlation is highly likely for other climatic events during MIS 3. An out-of-phase relationship is 
especially unlikely, as the time offset between negative and positive peaks is beyond the age uncertainty.

The age-depth curve of the fine-tuned age model was compared with the age model based only on ${ }^{14} \mathrm{C}$ datums in Additional file 3: Figure S3. The fine-tuned age model did not contradict the ${ }^{14} \mathrm{C}$-based ages as the obtained ages with the fine-tuned age model at the horizons of the ${ }^{14} \mathrm{C}$ datums were within the $2 \sigma$ uncertainties (Fig. 2 and Additional file 3: Figure S3). The average linear sedimentation rates were approximately $40 \mathrm{~cm} / \mathrm{ka}$ during MIS 3 and $15 \mathrm{~cm} / \mathrm{ka}$ during the Holocene. The highest one $(\sim 50 \mathrm{~cm} / \mathrm{ka})$ was found at LGM to deglaciation. Our sampling interval is frequent enough to satisfy the required Nyquist frequency (1/500 year ${ }^{-1}$ in this case), which is $1 / 2$ of the expected frequency to obtain accurate peaks in a time series data. The time resolution of the ${ }^{14} \mathrm{C}$-based datums is $3-4 \mathrm{ka}$ as listed in Table 2. We assume that the age uncertainty of the sampling horizons between the datums is similar to those at the datums based on the linear age-depth relationship in our age model (Fig. 2).

\section{Salinity effect on $\mathrm{Mg} / \mathrm{Ca}$ calibration}

This section discusses the results derived from "no salinity correction" and "salinity correction." The temporal

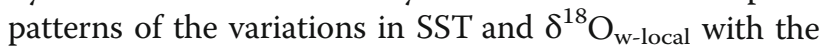
two calibrations agree well. However, the result with salinity correction for KR07-12 PC-01 shows less amplitude than that without salinity correction for both SST and $\delta^{18} \mathrm{O}_{\mathrm{w} \text {-local }}$ (Fig. 3), indicating that salinity effect on $\mathrm{Mg} /$ $\mathrm{Ca}$ amplifies the variability of SST. This is indicative in Fig. 3, showing that the positive correlation between SST and $\delta^{18} \mathrm{O}_{\mathrm{w} \text {-local }}$ is stronger in "no salinity correction" than in one with salinity correction for MIS 3 . Furthermore, these relationships depend on the sea level for the case without salinity correction, and the positive correlation becomes stronger as the sea level lowers (Fig. 3d, e). Given that the river mouth of the Changjiang River approaches as the sea level lowers, the sea-level dependence of the SST- $\delta^{18} \mathrm{O}_{\mathrm{w} \text {-local }}$ relationship reflects a change in salinity effect on the studied site in association with sea-level lowering. Alternatively, one would argue that the low sea-level stand prevents water inflow from the ECS to the Japan Sea, resulting in reduced freshwater transport into the Japan Sea and increased salinity variability in the northern ECS. Therefore, we conclude that SST and $\delta^{18} \mathrm{O}_{\mathrm{w}-\text { local }}$ reconstructions with salinity correction are a better estimate than the calibration without salinity correction.

\section{Calibrating the local salinity variations}

We interpret the $\delta^{18} \mathrm{O}_{\mathrm{w}-\text { local }}$ as a proxy for SSS and will refer to it in the discussion as such. In the modern ECS, a linear salinity- $\delta^{18} \mathrm{O}_{w}$ relationship is confirmed (e.g., Horikawa et al. 2015), reflecting mixing between the freshwater from the Changjiang River and seawater (Kuroshio Water) (e.g., Horikawa et al. 2015; Kubota et al. 2015). Namely, the salinity and $\delta^{18} \mathrm{O}_{\mathrm{w}}$ at the studied site can be interpreted in the context of a simplified two endmember mixing model of the freshwater from the Changiiang River and Kuroshio Water (Kubota et al. 2015). By contrast, the following factors are involved in controlling the ECS $\delta^{18} \mathrm{O}_{\mathrm{w}}$ in the past: (1) changes in $\delta^{18} \mathrm{O}_{\mathrm{w}}$ and salinity in the source region and (2) changes in mixing ratio between the Changjiang River freshwater and Kuroshio Water ( $\fallingdotseq$ salinity at the studied site). An effect of the global ice volume is also involved in the changes in endmember $\delta^{18} \mathrm{O}_{\mathrm{w}}$ and salinity. As the calibration method of "endmember correction" described in the "Methods/Experimental" section incorporates the changes in endmember $\delta^{18} \mathrm{O}_{\mathrm{w}}$ and salinity in the source region through time, the result derived from these calculations gives a better estimate, especially for the salinity. As a result, neither SST nor $\delta^{18} \mathrm{O}_{\mathrm{w}}$ with "endmember correction" has a large difference from those with "salinity correction" (Fig. 3), indicating that the "salinity correction" is a reasonably close approximation of those variabilities.

We utilized the $\delta^{18} \mathrm{O}_{\mathrm{sp}}$ data as the input parameter to determine the freshwater $\delta^{18} \mathrm{O}$ (Eq. 7) in the "endmember correction" method. In this method, we assume that the variability of the freshwater $\delta^{18} \mathrm{O}$ is the same as that of the $\delta^{18} \mathrm{O}_{\mathrm{sp}}$. In general, $\delta^{18} \mathrm{O}_{\mathrm{sp}}$ can be regarded as a function of drip water $\delta^{18} \mathrm{O}$ and cave temperature, unless precipitation of the speleothems is at equilibrium (Hendy 1971). When drip water $\delta^{18} \mathrm{O}$ increases and/or cave temperature decreases, the $\delta^{18} \mathrm{O}_{\mathrm{sp}}$ increases. The absence of any identification of the kinetic effect on the published $\delta^{18} \mathrm{O}_{\mathrm{sp}}$ from the Chinese caves enables us to interpret the $\delta^{18} \mathrm{O}_{\mathrm{sp}}$ as reflecting drip water $\delta^{18} \mathrm{O}$ and cave temperature (Wang et al. 2008). The assumption we apply to Eq. 7 does not incorporate the temperature component in estimating the endmember freshwater $\delta^{18} \mathrm{O}$. However, the cave temperature variability, if it is deduced from the SST in the ECS, would be correlated with the temporal variation in $\delta^{18} \mathrm{O}_{\mathrm{sp}}$ (Additional file 3: Figure S3). Thus, incorporating the temperature component is supposed to suppress the variability of the endmember freshwater $\delta^{18} \mathrm{O}$ and the calculation without the temperature component results in giving a maximum range of the variability of the freshwater $\delta^{18} \mathrm{O}_{\mathrm{w}}$. Moreover, high variability in the freshwater $\delta^{18} \mathrm{O}$ is expected to decrease the salinity variability or freshwater contribution in the northern ECS (Eqs. 6 and 7). Nevertheless, the SSS reconstruction with "endmember correction" still shows high variability in KR07-12 PC-01 (ca. \pm 1 ) during MIS 3 (Fig. 3), indicating that the changes in 
endmember $\delta^{18} \mathrm{O}_{\mathrm{w}}$ have little impact in the northern ECS. Even though the freshwater $\delta^{18} \mathrm{O}$ is highly variable with the amplitude of $\pm 1 \%$, its effect is diminished at the studied site due to a smaller contribution of the freshwater to the northern ECS compared with the seawater. Furthermore, neither the variability in $\delta^{18} \mathrm{O}_{w}$ nor the salinity in the western Pacific warm pool has a significant impact on the SSS reconstruction in the ECS.

\section{Changes in SST, local seawater $\delta^{18} \mathrm{O}$, and SSS}

The output data from "endmember correction" will be used for discussion hereafter. As planktic foraminifer $G$. ruber s.s. is abundant in warm seasons in the northern ECS (Yamasaki et al. 2010), we interpret that our results reflect the signals of the warm months (Kubota et al. 2015). The $\delta^{18} \mathrm{O}$, SST, and $\delta^{18} \mathrm{O}_{\mathrm{w} \text {-local }}$ of KR07-12 PC-01 replicate those of U1429 (Additional file 3: Figure S3), but have higher time resolution. The SST of core KR07-12 PC-01 ranges from $20.2^{\circ} \mathrm{C}$ to $24.4^{\circ} \mathrm{C}$, with an average of $22.3 \pm 0.7^{\circ} \mathrm{C}(1 \sigma)$ during MIS 3 (Figs. 3 and 4), characterized by $1-3^{\circ} \mathrm{C}$ amplitude variations at the millennial scale. The SST increases at D-O interstadials 10 and 9 in Greenland and decreases in association with Heinrich event 4 (H4). Four high SST events from 38 to $32 \mathrm{ka}$ can be correlated to D-O interstadials $8-5$. Heinrich event $3(\mathrm{H} 3)$ is recognizable, but the magnitude of the decrease in SST is similar to other SST minima. While D-O interstadial 3 is evident in the SST records, $\mathrm{D}-\mathrm{O}$ interstadial 4 is less distinct. Heinrich event $2(\mathrm{H} 2)$ is characterized by a pronounced decrease in SST by $3{ }^{\circ} \mathrm{C}$. The average SST in LGM is $22.3^{\circ} \mathrm{C}$, which is the same as that in MIS 3. Thus, the LGM is not the coldest period in the last $44 \mathrm{ka}$. This is a regional phenomenon as a similar trend is found in the middle Okinawa Trough (Chen et al. 2010) and western Pacific warm pool (Stott et al. 2002) based on $\mathrm{Mg} / \mathrm{Ca}$-based SST from G. ruber. However, alkenone-based SST, which is interpreted as reflecting an annual mean SST, shows the lowest values during LGM in the northern ECS (Ijiri et al. 2005; Clemens et al. 2018). The proxy-dependent results suggest seasonality in the SST evolution since the last glacial period.

The SSS in the northern ECS is highly variable, ranging from 31.5-34.0 during MIS 3. Millennial-scale variation is recognized in SSS with major negative peaks in association with D-O interstadials $10-5$ and 3 (Fig. 4). A predominant positive shift is found at $\mathrm{H} 4$, while $\mathrm{H} 3$ is less distinct. SST and SSS tend to covary on the millennial scale (H4, D-O 8, D-O 5, and H3). Contrary to the other high SSS events in association with $\mathrm{H} 4$ and $\mathrm{H} 3$, $\mathrm{H} 2$ is characterized by a negative shift, which suggests an alternative underlying mechanism of the EASM precipitation.
Regional and global factors affecting the Japan Sea records Temporal variation in lightness $\left(\mathrm{L}^{*}\right)$ of the hemipelagic sediments in the Japan Sea shows a millennial-scale temporal change similar to $\delta^{18} \mathrm{O}$ of the Greenland ice cores (Tada et al. 1995; Wang and Oba 1998; Tada et al. 1999). The $L^{*}$ of the sediment principally reflects organic carbon content $\left(\mathrm{C}_{\mathrm{org}}\right)$, which is controlled by primary production and burial rate, except for during the lowest sea-level stand, such as LGM, when $L^{*}$ is affected by pyrite content (Tada et al. 1999). Tada et al. (1999) suggested that changes in freshwater discharge from the Changjiang and Yellow Rivers, and consequent changes in the spatial extent of the nutrient-rich and low-salinity ECS coastal water, were the main cause of changes in a nutrient influx into the Japan Sea, and primary production there during MIS 3. The increased influence of the ECS coastal water not only enhanced primary productivity, but also reduced deep-water ventilation, leading to the development of the anoxic bottom waters and deposition of the dark layers (Tada et al. 1999; Irino et al. 2018). This hypothesis can be tested by comparing the temporal variations in the SSS in the northern ECS with $L^{*}$ of the hemipelagic sediments in the Japan Sea (Watanabe et al. 2007). While the nutrient and salinity flux into the Japan Sea is regulated by the EASM, the strength of the East Asian winter monsoon (EAWM) is a crucial factor to form a high-oxygenated deep-water mass called the Japan Sea Proper Water (JSPW) (Suda 1932; Nitani 1972; Ikehara and Fujine 2012; Gamo et al. 2014). The cold winds of the winter monsoon cool the surface water along the far eastern coast of Russia and promote the formation of sea ice, which increases the sea surface density to form the JSPW (Suda 1932; Nitani 1972). In addition to the factors described above, sea-level change controls the influx of the ECS waters into the Japan Sea as the narrow and shallow Tsushima Strait prevents the inflow of the ECS waters at a low sea-level stand. As the Japan Sea is connected to other ocean basins only through shallow $(<130 \mathrm{~m}$ in sill depth) and narrow $(<90 \mathrm{~km}$ in width) straits in addition to the Tsushima Strait, the sea-level change and resulting restriction of the seawater inflow from other basins are crucial to control the SSS in the Japan Sea. Thus, the following three climatic/oceanic factors that potentially control the sediment color of the Japan Sea are discussed in this section: (1) SSS in the northern ECS, (2) EAWM strength, and (3) global sea-level change. Factors 1 and 3 regulate the nutrient influx into the Japan Sea, while all three factors are involved in the deep-water formation and decomposition of the organic material in the sediment-water interface on the sea floor.

In this study, we used a high time resolution $(1 \mathrm{~cm}$ interval) $L^{*}$ record of core MD01-2407 in the Japan Sea (Bassinot and Blatzer 2002), which was recalibrated to calendar ages using Marine13 (Additional file 5, Additional file 6: 


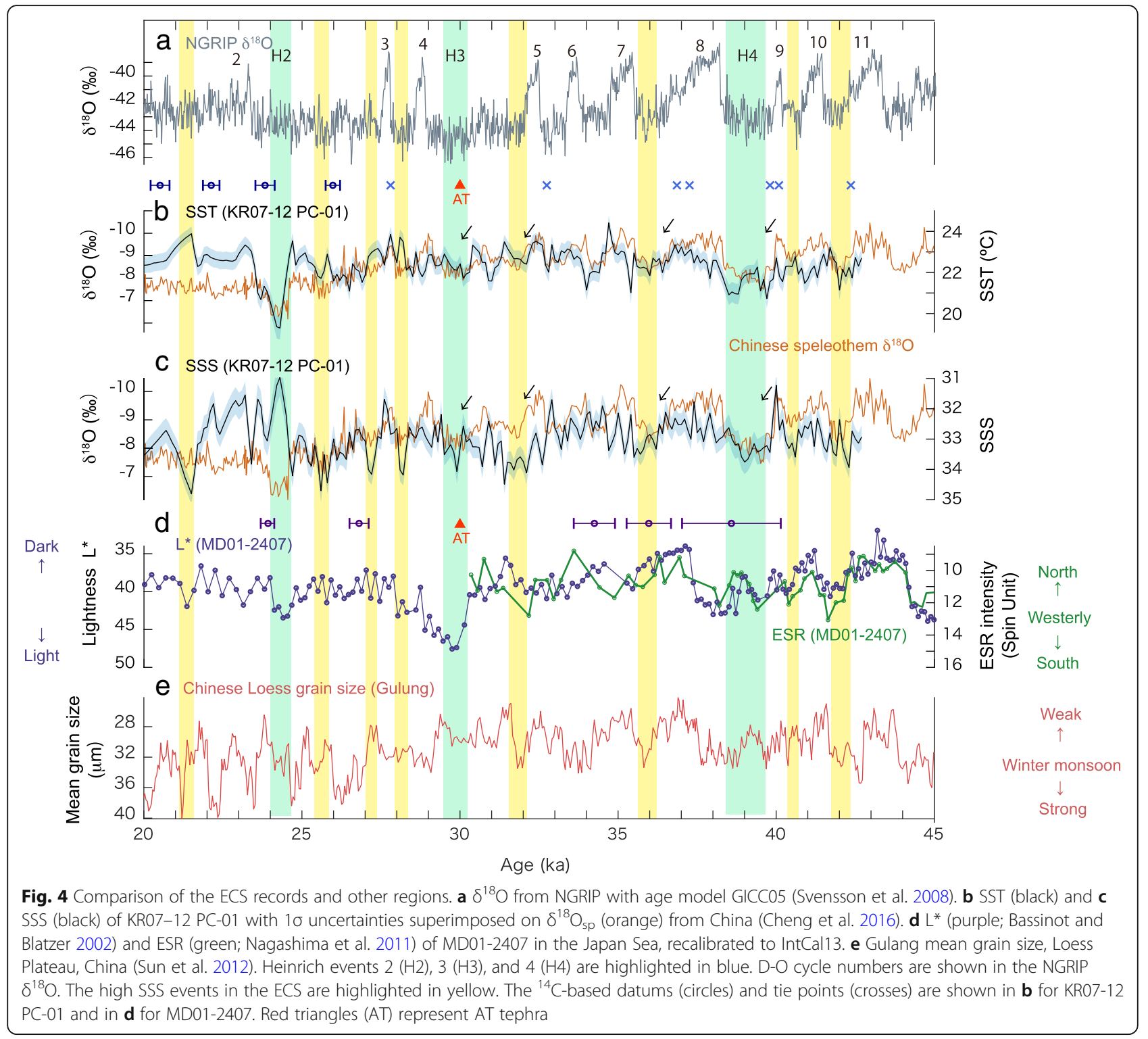

Figure S4, and Additional file 7: Table S2), for comparison among the records (Fig. 4). The temporal resolution of the $1 \mathrm{~cm}$ interval data is approximately 120 years. In the intervals 44-34 ka (D-O11-7) and 30-28 ka (H3-D-O 4), the Japan Sea L* profile varies in phase with the northern ECS SSS. The dark (light) layers are correlated to the low (high) SSS in the northern ECS. Since AT tephra is found in both cores, the timing of each environmental change in both seas can be constrained (Fig. 2). In the Japan Sea, AT tephra is found at the base of the light later (H3), which is correlated with one of the high SSS events in the ECS. Based on the comparison above, the changes in the SSS in the northern ECS and consequent changes in nutrient and salinity input into the Japan Sea had been a dominant factor altering the sediment color in the Japan Sea in these intervals. The variations in SSS in the northern ECS and associating surface water density in the Japan Sea had been amplifying the variability of the sediment color through the process of production of deep water (Tada et al. 1999). The variations in the EAWM probably had also enhanced the variability of the sediment color during this time period. In fact, a high-resolution quartz grain size record of loess from Gulang section in the Chinese Loess Plateau, which is an indicator of EAWM, shows a good correlation with the $\mathrm{L}^{*}$ during the interval 44-34 ka. By contrast, the millennial-scale linkage between the northern ECS and Japan Sea became less clear after $34 \mathrm{ka}$, which is probably linked to the sea-level lowering. Lambeck et al. (2014) have reported a rapid sea-level fall (by $\sim 40 \mathrm{~m}$ in less than 2000 years) at $\sim 30 \mathrm{ka}$, following the gradual fall starting from $\sim 35 \mathrm{ka}$. The rapid and substantial fall in sea level from $\sim-80$ to $\sim-120 \mathrm{~m}$ at $30 \mathrm{ka}$ 
would have reduced the water exchange between the northern ECS and Japan Sea from 20\% of today to almost zero (Additional file 8: Figure S5). Previous studies have revealed that the SSS in the Japan Sea had been lowering toward LGM, which was inferred from a shift to low values in planktic foraminiferal $\delta^{18} \mathrm{O}$ in the Japan Sea after $30 \mathrm{ka}$ (Oba et al. 1991; Kido et al. 2007; Sagawa et al. 2018). The sediment facies of the dark layers also shifted from bioturbated layers interbedded by fine laminations to finely laminated layers in association with the decrease in the SSS in the Japan Sea around $28 \mathrm{ka}$ (Watanabe et al. 2007). This facies change is accompanied by an increase in $\mathrm{S} / \mathrm{C}_{\mathrm{org}}$, suggesting the euxinic condition in the bottom water (Watanabe et al. 2007), likely caused by the poor ventilation of the bottom water and not by the increase in the primary productivity, as the nutrient input from the ECS was reduced significantly (Watanabe et al. 2007). The comparison of the SSS in the ECS and L* in this study indicates that they are not correlated well in this interval, suggesting the millennial-scale variations in the ECS SSS had almost no impact on the Japan Sea at the lower sea level. Thus, there seems to be a threshold around the sea level of -80 to $-120 \mathrm{~m}$ from a mode where the Japan Sea responds well to the ECS variation to the other mode where it does not. Meanwhile, one still can find interbedded light layers, such as H2, after $28 \mathrm{ka}$ (Watanabe et al. 2007). These light layers might be caused by a different mechanism from those during MIS 3. We speculate that deposition of the light layers might be involved in a millennial-scale sea-level rise that increases the ECS water influx to increase the density of the Japan Sea. In this case, the deep water ventilation plays a more significant role in controlling the $\mathrm{L}^{*}$. Although the timing of the rapid sea-level rise is an issue (Yokoyama and Esat 2011), based on studies on an oxygen isotope record from the Red Sea and isotopes in corals from Papua New Guinea, it is now accepted that 15-20 m, and possibly up to $30 \mathrm{~m}$, of sea level increases is associated with Heinrich events (Broecker 1994; Siddall et al. 2003; Yokoyama and Esat 2011), or with the warm period after the termination of a Heinrich event (Arz et al. 2007). A change in sea level of $15-20 \mathrm{~m}$ corresponds to over $10 \%$ change in the cross section in the Tsushima Strait, potentially leading a massive change in the water volume exchange between the two ocean basins.

\section{Summer precipitation variability and westerly jet in East Asia}

The most prominent feature in our new records is that the SSS in the ECS varies in association with the D-O cycles, which can provide fundamental information on summer precipitation changes under the EASM system. Although the Chinese $\delta^{18} \mathrm{O}_{\mathrm{sp}}$ is one of the most well-known proxies from the EASM region, the interpretation of the Chinese $\delta^{18} \mathrm{O}_{\mathrm{sp}}$ is still controversial on a millennial-scale (e.g., Zhang et al. 2018). In the earlier stage of the studies on $\delta^{18} \mathrm{O}_{\mathrm{sp}}$, the $\delta^{18} \mathrm{O}_{\mathrm{sp}}$ were interpreted as the amount of summer precipitation at a given cave location (Wang et al. 2001). Subsequently, other interpretations were proposed: the fraction of water vapor removed from air masses along the moisture trajectory between the tropical Indo-Pacific and the cave sites $(\mathrm{Hu}$ et al. 2008) or isotopic fluctuation in the moisture source region (Pausata et al. 2011). By contrast, the most recent study argued that the $\delta^{18} \mathrm{O}_{\mathrm{sp}}$ is better understood as a measure of the large-scale monsoon circulation, not reflecting the local precipitation (Liu et al. 2014). This interpretation is also put forward in a study on trace elements of speleothems, which suggests a wetter condition in $\mathrm{H} 1$ and Younger Dryas during the last deglaciation (Zhang et al. 2018). In their discussion, when the $\delta^{18} \mathrm{O}_{\mathrm{sp}}$ becomes heavier, which is traditionally interpreted as "weak monsoon," the local summer rainfall increases in the Changjiang River catchment basin (Zhang et al. 2018). Our new SSS result indicates that most D-O stadials and $\mathrm{H} 4$ and $\mathrm{H} 3$ intervals correspond to less EASM precipitation and D-O interstadials correspond to more EASM precipitation. Our result contradicts what was claimed in Zhang et al. (2018), suggesting that the millennial-scale summer precipitation response might depend on a global climate setting, such as sea level. In fact, $\mathrm{H} 2$ in the ECS, characterized by the decreased SSS, is different from other stadials and Heinrichs. A complex response in the summer precipitation was also suggested based on pollen record from Lake Suigetsu, central Japan, which indicates a wetter condition during H1 compared to the following Bølling-Allerød (Nakagawa et al. 2006).

The SSS variation in the ECS and its relationship to the westerly jet will give us a new insight into the variability of summer precipitation and its relationship to monsoon circulation itself. Today, the EASM front migrates northward from South China from May and reaches the North China-Inner Mongolia regions in $\mathrm{Au}$ gust. From the meteorological aspect, the northward migration of the EASM front follows the northward shift of the westerly jet over East Asia on a seasonal scale (Sampe and Xie 2010). Therefore, a proxy of the position of the westerly jet is regarded as an indicator of the EASM circulation. On an interannual time scale, the negative correlation between EASM rainfall in the Changjiang River basin and the summer southerly wind intensity in the northernmost region of the EASM was observed (Jiang et al. 2008); the EASM circulation was stronger, and the Changjiang River basin had less precipitation. A similar relationship was observed on a millennial-scale during the Holocene, based on a proxy of the westerly jet and summer precipitation records from inland China and ECS (Nagashima et al. 2013). 
According to Nagashima et al. (2011), the position of the westerly jet has varied in harmony with D-O cycles in MIS 3, based on the electron spin resonance (ESR) signal intensity of quartz in the fine silt fraction of the Japan Sea sediments, which is interpreted as a proxy for dust provenance, sourced either from the Taklimakan Desert or the Mongolian Gobi (Fig. 4). The higher (lower) ESR signal intensity during stadials (interstadials) suggests the southern (northern) position of the westerly jet and weaker (stronger) EASM circulation (Nagashima et al. 2011). In the interval 44-34 ka, the increased EASM precipitation in the Changjiang River basin followed the northward shift of the westerly jet position (EASM front), which was opposite to what was observed on a millennial-scale during the Holocene (Nagashima et al. 2013) and on an interannual to decadal scale today (e.g., Jiang et al. 2008).

\section{Global context of East Asian monsoon variations}

A comparison of the Chinese $\delta^{18} \mathrm{O}_{\mathrm{sp}}$ record and loess grain size indicates that the EASM and EAWM are coupled on a millennial time scale during the interval 60-34 ka (Sun et al. 2012). Their variations are well correlated to the North Atlantic climate variability as well (Sun et al. 2012). In the study of Sun et al. (2012), North Atlantic water-hosing experiments, using the Community Climate System Model Version 3 to mimic the Heinrich or stadial events, suggest a dynamical response of the EASM and EAWM systems to the suppressed Atlantic Meridional Overturning Circulation (AMOC) and cooling in the North Atlantic. The freshwater forcing increases the latitudinal temperature gradient and induces stronger EAWM during winter (Sun et al. 2012). During summer, cooling in North Atlantic results in a southward shift of the Intertropical Convergence Zone, followed by a stronger Walker circulation and weaker EASM (Zhang and Delworth 2005). The moisture convergence along the EASM front and precipitation in the Changjiang River basin is suppressed as the North Pacific subtropical high weakens in response to the freshwater forcing during summer (Sun et al. 2012). However, an opposite summer precipitation response is suggested in a numerical simulation using the Community Earth System Model (Zhang et al. 2018). In this simulation, a stronger meridional temperature gradient, and resultant southward-shifted and strengthened westerly jet, leads to enhanced convection along the slope of the Tibetan Plateau, increased precipitation in southern China, and decreased precipitation in northern China. Thus, the precipitation response in the East Asian monsoon region depends on the climate models, being not constrained by the numerical models as depicted in Kageyama et al. (2013). Conversely, our records give a constraint on the mechanism of the EASM response to AMOC variability during MIS 3, suggesting that the decreased precipitation in Heinrichs is caused by the reduction of the moisture supply from the surrounding oceans, probably linked to the weakening of the subtropical high in the North Pacific (Sun et al. 2012). We infer that, under this mechanism, the migration pattern of the westerly jet and associated position of the EASM front do not regulate the special summer precipitation distribution in the same manner as today, but moisture budget in the atmosphere plays a dominant role. However, an alternative explanation is required for the opposing precipitation trend, such as $\mathrm{H} 2$ and $\mathrm{H} 1$, when the summer precipitation pattern is opposite to what is observed for MIS 3. A recent study points out that the internal climate variability is important in the rainfall variation in East Asia's mid-latitude on an interannual and decadal scale today (Ueda et al. 2015). Internal variability is the natural variability of the climate system that occurs in the absence of external forcing, and includes processes intrinsic to the atmosphere, the ocean, and the coupled ocean-atmosphere system (Deser et al. 2010; Deser et al. 2012). Interannual and decadal scale variabilities arise from the intrinsic variability of the system due to a random stochastic process and results from dynamic and thermodynamic interactions of the coupled ocean-atmosphere system (Deser et al. 2012). Ueda et al. (2015) argue that today's interannual and interdecadal precipitation pattern over mid-latitude East Asia is caused by a combination of the atmospheric internal variability and SST in the western Pacific and Indian Ocean. On a millennial time scale, the EAWM variability after $30 \mathrm{ka}$, decoupled to the North Atlantic climate (Sun et al. 2012), appears to lack the forcing outside of the East Asian climate system, perhaps resulting from the increased intrinsic variability of the EAWM. One would argue that the increased summer precipitation in southern China in $\mathrm{H} 2$ and $\mathrm{H} 1$ is interpreted as reflecting the increased convection along the slope of the Tibetan Plateau, induced by the longer placement of the EASM front in the southern position (Zhang et al. 2018). Alternatively, however, the summer precipitation response in $\mathrm{H} 2$ and $\mathrm{H} 1$ may be explained in the context of the random stochastic processes in the EASM system as well as the EAWM. In the latter case, the overall monsoon system in East Asia would randomly vary, rather than responding to the North Atlantic forcing during MIS 2. Either way, the opposite millennial-scale EASM precipitation pattern during MIS 2 leads to a conclusion that the regional precipitation is not a dominant factor controlling the millennial-scale Chinese $\delta^{18} \mathrm{O}_{\mathrm{sp}}$ in this period.

\section{Conclusion}

We reconstructed SST, $\delta^{18} \mathrm{O}_{\mathrm{w}}$-local, and SSS using the paired $\mathrm{Mg} / \mathrm{Ca}$ and $\delta^{18} \mathrm{O}_{\mathrm{p}}$ in the northern ECS. To better estimate the SSS variability, we tested the three calibration methods to reconstruct these records. The SST record derived from the $\mathrm{Mg} / \mathrm{Ca}$ calibration without salinity 
correction shows higher variability than the one with salinity correction, and its variability depends on the sea level. The SSS reconstruction is not significantly affected by the endmember $\delta^{18} \mathrm{O}_{\mathrm{w}}$ and salinity variability in the source regions, indicating that the modern local $\delta^{18} \mathrm{O}_{\mathrm{w}}$-salinity calibration is applicable to the MIS 3 case. The most prominent feature of our SSS record is the millennial-scale variations in association with the D-O cycle in Greenland and the Chinese $\delta^{18} \mathrm{O}_{\mathrm{sp}}$, where high SSS events coincide with D-O stadials and Heinrichs, while low SSS events coincide with D-O interstadials. The comparison of the SSS in the northern ECS, the proxy of the EAWM, and the sediment color in the Japan Sea reveal that the changes in nutrient and salinity flux in the Japan Sea induced by the Changjiang River discharge in addition to the strength of the EAWM are likely the primary factors determining the surface productivity changes manifesting as color changes in the sediments of the Japan Sea when the sea level was higher than ca. $-80 \mathrm{~m}$. The glacioeustatic sea-level changes reduced the influx of the ECS coastal water entering into the Japan Sea, especially after $\sim 30 \mathrm{ka}$, at which the linkage between the SSS in the northern ECS and the sediment color of the Japan Sea became less clear.

The SSS variation in the ECS and its relationship to the westerly jet indicates that the decreased EASM precipitation in the Changjiang River basin followed the southward shift of the westerly jet position, which is opposite to what was observed on a millennial-scale during the Holocene and interannual time scale today. We infer that the moisture convergence along the EASM front and overall moisture budget in the atmosphere, which would be altered in association with the D-O cycles and Heinrichs, plays a dominant role in controlling the EASM precipitation in southern China during MIS 3. The precipitation response during MIS 2 is opposite to MIS 3, suggesting the alternative mechanism involved at different global climate backgrounds.

\section{Additional files}

Additional file 1: Figure S1. (a) Mg/Ca vs. Mn/Ca of KR07-12 PC-01 (all range) and (b) Mg/Ca vs. Mn/Ca (0-200 $\mu \mathrm{mol} / \mathrm{mol})$. (PDF $201 \mathrm{~kb})$

Additional file 2: Figure S2. Comparison among $\delta^{18} \mathrm{O}_{w}$ of KR07-12 PC01 (red) and $\delta^{18} \mathrm{O}_{w}$ of endmembers. The freshwater endmember is derived from Chinese speleothem $\delta^{18} \mathrm{O}$ (blue; Cheng et al. 2016), and Kuroshio Water endmember is derived from MD06-3067 (purple; Bolliet et al. 2011). The vertical axis on the left is for the freshwater endmember and on the right is for KR07-12 PC-01 and MD06-3067. (PDF $165 \mathrm{~kb}$ )

Additional file 3: Figure S3. Comparison of the results of KR07-12 PC01, U1429 (Clemens et al. 2018), and Chinese speleothem $\delta^{18} \mathrm{O}\left(\delta^{18} \mathrm{O}_{\mathrm{sp}}\right)$ with (a) ${ }^{14} \mathrm{C}$-based age and (b) fine-tuned age. The top panels show comparisons between the planktic foraminiferal $\delta^{18} \mathrm{O}\left(\delta^{18} \mathrm{O}_{p}\right)$ of KR07-12 PC-01 and U1429 and $\delta^{18} \mathrm{O}_{\text {sp. }}$. The middle and bottom panels show SST and local $\delta^{18} \mathrm{O}_{w}\left(\delta^{18} \mathrm{O}_{w-\text { local }}\right)$, respectively. Open circles on the top of the figure represent the ${ }^{14} \mathrm{C}$-based datums and $2 \sigma$ uncertainties. Crosses and triangles in the right panel indicate the tie points and the ages of the horizons of ${ }^{14} \mathrm{C}$ datums with the fine-tuned age model, respectively. (PDF $276 \mathrm{~kb}$ )

Additional file 4: Table S1. The tie points of the fine-tuned age model of KR07-12 PC-01. (XLS 27 kb)

Additional file 5: Age model for MD01-2407. AMS ${ }^{14} \mathrm{C}$ ages for core MD01-2407 published in Yokoyama et al. (2007) were recalibrated to calendar age with Marine13 $(\Delta R=45)$ (Reimer et al. 2013). All of the calendar age and depths are listed in Table S1. Choosing a reasonable sedimentation rate, seven datums were not employed in our age model (Table S1). Before 50 ka, we refer to datums in Kido et al. (2007). (DOCX 15 kb)

Additional file 6: Figure S4. Depth vs. calendar age for core MD012407. Data in blue are not used for the age model. (PDF $75 \mathrm{~kb}$ )

Additional file 7: Table S2. The calendar ages and depths for core MD01-2407 and references. (XLSX $10 \mathrm{~kb}$ )

Additional file 8: Figure S5. Depth in the Tsushima Strait vs. crosssection area in the Tsushima Strait (Oba 1988). (PDF 70 kb)

\section{Abbreviations}

EASM: East Asian summer monsoon; EAWM: East Asian winter monsoon; ECS: East China Sea; JSPW: Japan Sea Proper Water; LGM: Last Glacial Maximum; MIS: Marine Isotope Stage; $\delta^{18} \mathrm{O}$ : Oxygen isotope; $\delta^{18} \mathrm{O}_{\mathrm{p}}$ : Oxygen isotope of planktic foraminifera; $\delta^{18} \mathrm{O}_{\mathrm{sp}}$ : Oxygen isotope of speleothems; $\delta^{18} \mathrm{O}_{\mathrm{w}}$ : Oxygen isotope of water; $\delta^{18} \mathrm{O}_{w-\text { local: }}$ Oxygen isotope of local seawater

\section{Acknowledgments}

We thank the onboard scientists and cruise staffs of KR07-12. We also thank T. Omura, H. Yamamoto, M. Takada, M. Sato, Y. Nakamura, N. Kisen, N. Nakamura, and A. Kobayashi for their assistance in our experiments. We are grateful to K. Nagashima, T. Sagawa, T. Irino, and T. Nakagawa for their helpful comment and suggestion.

\section{Funding}

JSPS KAKENHI Grant supported this work number 23221022 awarded to RT, and grants from the National Museum of Nature and Science and Japan Agency for Marine-Earth Science and Technology (JAMSTEC) from the Ministry of Education, Culture, Sports, Science, and Technology (MEXT, Japan). A grant-in-aid funded YK for JSPS Fellows, grant number 10914, and Program for Advancing Strategic International Networks to Accelerate the Circulation of Talented Researchers, grant number R2901.

\section{Availability of data and materials}

The datasets used and/or analysed during the current study are available from the corresponding author on reasonable request.

\section{Declarations}

The data sets supporting the conclusions of this article are included in this article and its additional files.

\section{Authors' contributions}

RT proposed the topic for YK's doctoral research. YK carried out the experimental study under the guidance of RT and KK. MU and KI analyzed the ${ }^{14} \mathrm{C}$ and tephra, respectively, and helped in their interpretation. YK wrote a draft of the manuscript, and RT collaborated with the corresponding author in the construction of the manuscript. All authors read and approved the final manuscript.

\section{Authors' information}

RT was a co-chief scientist of KR07-12, and YK and KI were on-board scientists of KR07-12. RT and KK supervised YK's doctoral research.

\section{Competing interests}

The authors declare that they have no competing interests.

\section{Publisher's Note}

Springer Nature remains neutral with regard to jurisdictional claims in published maps and institutional affiliations. 


\section{Author details}

'Department of Geology and Paleontology, National Museum of Nature and Science, 4-1-1, Amakubo, Tsukuba, Ibaraki 305-0005, Japan. ${ }^{2}$ Research Institute for Global Change, Japan Agency for Marine-Earth Science and Technology, 2-15 Natsushima-Cho, Yokosuka, Kanagawa 237-0061, Japan. ${ }^{3}$ Department of Earth and Planetary Science, Graduate School of Science, The University of Tokyo, 7-3-1, Hongo, Bunkyo-Ku, Tokyo 113-0033, Japan. ${ }^{4}$ National Institute for Environmental Studies, 16-2 Onogawa, Tsukuba, Ibaraki 305-8506, Japan. ${ }^{5}$ Geological Survey of Japan, National Institute of Advanced Industrial Science and Technology, 1-1-1 Higashi, Tsukuba 305-8567, Japan.

\section{Received: 2 August 2018 Accepted: 18 April 2019}

\section{Published online: 28 May 2019}

\section{References}

Andres M, Park J-H, Wimbush M, Zhu X-H, Chang K-I, Ichikawa H (2008) Study of the Kuroshio/Ryukyu current system based on satellite-altimeter and in situ measurements. J Oceanogr 64:937-950. https://doi.org/10.1007/s10872-008$0077-2$

Antonov Jl, Seidov D, Boyer TP, Locarnini RA, Mishonov AV, Garcia HE, Baranova OK, Zweng MM, Johnson DR (2010) World ocean atlas 2009, volume 2: salinity. U.S. Government Printing Office, Washington, D.C.

Arz HW, Lamy F, Ganopolski A, Nowaczyk N, Pätzold J (2007) Dominant Northern Hemisphere climate control over millennial-scale glacial sea-level variability. Quat Sci Rev 26:312-321. https://doi.org/10.1016/j.quascirev.2006.07.016

Bassinot F, Blatzer A (2002) WEPAMA Cruise MD 122 - IMAGES VII: Leg 1, Port Hedland (Australia), 01-05-2001 to Keelung (Taiwan), 26-05-2001; Leg 2, Keelung (Taiwan), 27-05-2001 to Kochi (Japan), 18-06-2001. Institut Polaire Français Paul-Emile Victor

Bemis BE, Spero HJ, Bijma J, Lea DW (1998) Reevaluation of the oxygen isotopic composition of planktonic foraminifera: experimental results and revised paleotemperature equations. Paleoceanography 13:150-160

Bolliet T, Holbourn A, Kuhnt W, Laj C, Kissel C, Beaufort L, Kienast M, Andersen N, Garbe-Schönberg D (2011) Mindanao dome variability over the last 160 kyr: episodic glacial cooling of the West Pacific warm pool. Paleoceanography 26: 1050-1018. https://doi.org/10.1029/2010PA001966

Boyle EA, Keigwin LD (1985) Comparison of Atlantic and Pacific paleochemical records for the last 215,000 years: changes in deep ocean circulation and chemical inventories. Earth Planet Sci Lett 76:135-150. https://doi.org/10. 1016/0012-821X(85)90154-2

Broecker WS (1994) Massive iceberg discharges as triggers for global climate change. Nature 372:421-424. https://doi.org/10.1038/372421a0

Chen C, Beardsley RC, Limeburner R, Kim K (1994) Comparison of winter and summer hydrographic observations in the Yellow and East China Seas and adjacent Kuroshio during 1986. Cont Shelf Res 14:909-928

Chen MT, Lin XP, Chang YP, Chen YC, Lo L, Shen CC, Yokoyama Y, Oppo DW, Thompson WG, Zhang R (2010) Dynamic millennial-scale climate changes in the northwestern Pacific over the past 40,000 years. Geophys Res Lett 37: L23603. https://doi.org/10.1029/2010GL045202

Cheng H, Edwards RL, Sinha A, Spötl C, Yi L, Chen S, Kelly M, Kathayat G, Wang X, Li X, Kong X, Wang Y, Ning Y, Zhang H (2016) The Asian monsoon over the past 640,000 years and ice age terminations. Nature 534:640-646. https://doi. org/10.1038/nature18591

Cheng H, Edwards RL, Southon J, Matsumoto K, Feinberg JM, Sinha A, Zhou W, Li H, Li X, Xu Y, Chen S, Tan M, Wang Q, Wang Y, Ning Y (2018) Atmospheric ${ }^{14} \mathrm{C} /{ }^{12} \mathrm{C}$ changes during the last glacial period from Hulu Cave. Science 362 : 1293-1297. https://doi.org/10.1126/science.aau0747

Clemens SC, Holbourn A, Kubota Y, Lee KE, Liu Z, Chen G, Nelson A, Fox-Kemper $B$ (2018) Precession-band variance missing from East Asian monsoon runoff. Nat Commun 9:3364. https://doi.org/10.1038/s41467-018-05814-0

Clemens SC, Prell WL, Sun Y (2010) Orbital-scale timing and mechanisms driving Late Pleistocene Indo-Asian summer monsoons: reinterpreting cave speleothem $\delta^{18}$ O. Paleoceanography 25:PA4207. https://doi.org/10.1029/ 2010pa001926

Conroy JL, Thompson DM, Cobb KM, Noone D, Rea S, LeGrande AN (2017) Spatiotemporal variability in the $\delta^{18} \mathrm{O}$-salinity relationship of seawater across the tropical Pacific Ocean. Paleoceanography 32:484-497. https://doi.org/10. 1002/2016PA003073

Danhara T, Yamashita T, Iwano H, Kasuya M (1992) An improved system for measuring refractive index using the thermal immersion method. Quat Int 13-14:89-91
Dansgaard W, Johnsen SJ, Clausen HB, Dahl-Jensen D, Gundestrup NS, Hammer CU, Hvidberg CS, Steffensen JP, Sveinbjörnsdottir AE, Jouzel J, Bond G (1993) Evidence for general instability of past climate from a 250-kyr ice-core record. Nature 364:218-220

Dayem KE, Molnar P, Battisti DS, Roe GH (2010) Lessons learned from oxygen isotopes in modern precipitation applied to interpretation of speleothem records of paleoclimate from eastern Asia. Earth Planet Sci Lett 295:219-230. https://doi.org/10.1016/j.epsl.2010.04.003

Dekens PS, Lea DW, Pak DK, Spero HJ (2002) Core top calibration of Mg/Ca in tropical foraminifera: refining paleotemperature estimation. Geochem Geophys Geosyst 3:1-29. https://doi.org/10.1029/2001GC000200

Deser C, Knutti R, Solomon S, Phillips AS (2012) Communication of the role of natural variability in future North American climate. Nat Clim Chang 2:775779. https://doi.org/10.1038/nclimate1562

Deser C, Phillips A, Bourdette V, Teng H (2010) Uncertainty in climate change projections: the role of internal variability. Clim Dyn 38:527-546. https://doi. org/10.1007/s00382-010-0977-x

Gamo T, Nakayama N, Takahata N, Sano Y, Zhang J, Yamazaki E, Taniyasu S, Yamashita N (2014) The Sea of Japan and its unique chemistry revealed by time-series observations over the last 30 years. Monogr Environ Earth Planets 2:1-22

Hathorne EC, Gagnon A, Felis T, Adkins J, Asami R, Boer W, Caillon N, Case D, Cobb KM, Douville E, deMenocal P, Eisenhauer A, Garbe-Schönberg D, Geibert W, Goldstein S, Hughen K, Inoue M, Kawahata H, Kölling M, Cornec FL, Linsley BK, McGregor HV, Montagna P, Nurhati IS, Quinn TM, Raddatz J, Rebaubier H, Robinson L, Sadekov A, Sherrell R, Sinclair D, Tudhope AW, Wei G, Wong H, Wu HC, You C-F (2013) Interlaboratory study for coral Sr/Ca and other element/Ca ratio measurements. Geochem Geophys Geosyst 14:37303750. https://doi.org/10.1002/ggge.20230

Hendy CH (1971) The isotopic geochemistry of speleothems-I. The calculation of the effects of different modes of formation on the isotopic composition of speleothems and their applicability as palaeoclimatic indicators. Geochim Cosmochim Acta 35:801-824. https://doi.org/10.1016/0016-7037(71)90127-X

Horikawa K, Kodaira T, Zhang J, Murayama M (2015) $\delta^{18} \mathrm{O}_{\text {sw }}$ estimate for Globigerinoides ruber from core-top sediments in the East China Sea. Prog Earth Planet Sci 2:19. https://doi.org/10.1186/s40645-015-0048-3

Hu C, Henderson GM, Huang J, Xie S, Sun Y, Johnson KR (2008) Quantification of Holocene Asian monsoon rainfall from spatially separated cave records. Earth Planet Sci Lett 266:221-232. https://doi.org/10.1016/j.epsl.2007.10.015

Ichikawa H, Beardsley RC (1993) Temporal and spatial variability of volume transport of the Kuroshio in the East China Sea. Deep-Sea Res I Oceanogr Res Pap 40:583-605. https://doi.org/10.1016/0967-0637(93)90147-U

Ichikawa H, Beardsley RC (2002) The current system in the Yellow and East China Seas. J Oceanogr 58:77-92

ljiri A, Wang L, Oba T, Kawahata H, Huang CY (2005) Paleoenvironmental changes in the northern area of the East China Sea during the past 42,000 years. Palaeogeogr Palaeoclimatol Palaeoecol 219:239-261

Ikehara K, Fujine K (2012) Fluctuations in the Late Quaternary East Asian winter monsoon recorded in sediment records of surface water cooling in the northern Japan Sea. J Quat Sci 27:866-872. https://doi.org/10.1002/jgs.2573

Inoue M, Yoshida K, Minakawa M, Kiyomoto Y, Kofuji H, Nagao S, Hamajima Y, Yamamoto M (2012) Spatial variations of 226Ra, 228Ra, and 228Th activities in seawater from the eastern East China Sea. Geochem J 46:429-441

Irino T, Tada R, Ikehara K, Sagawa T, Karasuda A, Kurokawa S, Seki A, Lu S (2018) Construction of perfectly continuous records of physical properties for darklight sediment sequences collected from the Japan Sea during Integrated Ocean Drilling Program Expedition 346 and their potential utilities as paleoceanographic studies. Prog Earth Planet Sci 5:23. https://doi.org/10. 1186/s40645-018-0176-7

Isobe A, Ando M, Watanabe T, Senjyu T, Sugihara S, Manda A (2002) Freshwater and temperature transports through the Tsushima-Korea Straits. J Geophys Res 107:3065. https://doi.org/10.1029/2000jc000702

Japan Oceanographic Data Center (2004) Statistical Products. https://www.jodc. go.jp/jodcweb. Accessed 1 Apr 2019

Jia Q, Li T, Xiong Z, Steinke S, Jiang F, Chang F, Qin B (2018) Hydrological variability in the western tropical Pacific over the past $700 \mathrm{kyr}$ and its linkage to Northern Hemisphere climatic change. Palaeogeogr Palaeoclimatol Palaeoecol 493:44-54. https://doi.org/10.1016/j.palaeo.2017.12.039

Jiang Z, Yang S, He J, Li J, Liang J (2008) Interdecadal variations of East Asian summer monsoon northward propagation and influences on summer precipitation over East China. Meteorog Atmos Phys 100:101-119. https://doi. org/10.1007/s00703-008-0298-3 
Kageyama M, Merkel U, Otto-Bliesner B, Prange M, Abe-Ouchi A, Lohmann G, Ohgaito R, Roche DM, Singarayer J, Swingedouw D (2013) Climatic impacts of fresh water hosing under Last Glacial Maximum conditions: a multi-model study. Clim Past 9:935-953. https://doi.org/10.5194/cp-9935-2013

Kido Y, Minami I, Tada R, Fujine K, Irino T, Ikehara K, Chun JH (2007) Orbital-scale stratigraphy and high-resolution analysis of biogenic components and deepwater oxygenation conditions in the Japan Sea during the last $640 \mathrm{kyr}$. Palaeogeogr Palaeoclimatol Palaeoecol 247:32-49

Kim RA, Lee KE, Bae SW (2015) Sea surface temperature proxies (alkenones, foraminiferal Mg/Ca, and planktonic foraminiferal assemblage) and their implications in the Okinawa Trough. Prog Earth Planet Sci 2:1-16. https://doi. org/10.1186/s40645-015-0074-1

Kubota Y, Kimoto K, Tada R, Oda H, Yokoyama Y, Matsuzaki H (2010) Variations of East Asian summer monsoon since the last deglaciation based on $\mathrm{Mg} / \mathrm{Ca}$ and oxygen isotope of planktic foraminifera in the northern East China Sea. Paleoceanography 25:PA4205. https://doi.org/10.1029/2009PA001891

Kubota Y, Tada R, Kimoto K (2015) Changes in East Asian summer monsoon precipitation during the Holocene deduced from a freshwater flux reconstruction of the Changjiang (Yangtze River) based on the oxygen isotope mass balance in the northern East China Sea. Clim Past 11:265-281. https://doi.org/10.5194/cp-11-265-2015

Lambeck K, Rouby H, Purcell A, Sun Y, Sambridge M (2014) Sea level and global ice volumes from the Last Glacial Maximum to the Holocene. Proc Natl Acad Sci 111:15296-15303. https://doi.org/10.1073/pnas.1411762111

Lea DW, Mashiotta TA, Spero HJ (1999) Controls on magnesium and strontium uptake in planktonic foraminifera determined by live culturing. Geochim Cosmochim Acta 63:2369-2379

LeGrande AN, Schmidt GA (2011) Water isotopologues as a quantitative paleosalinity proxy. Paleoceanography 26:PA3225. https://doi.org/10.1029/2010pa002043

Liu Z, Wen X, Brady EC, Otto-Bliesner B, Yu G, Lu H, Cheng H, Wang Y, Zheng W, Ding Y, Edwards RL, Cheng J, Liu W, Yang H (2014) Chinese cave records and the East Asia summer monsoon. Quat Sci Rev 83:115-128. https://doi.org/10.1016/j.quascirev.2013.10.021

Locarnini RA, Mishonov AV, Antonov Jl, Boyer TP, Garcia HE (2010) World ocean atlas 2009, volume 1: temperature. U.S. Government Printing Office, Washington, D.C.

Maher BA, Thompson R (2012) Oxygen isotopes from Chinese caves: records not of monsoon rainfall but of circulation regime. J Quat Sci 27:615-624. https:// doi.org/10.1002/jqs.2553

Nagashima K, Tada R, Tani A, Sun Y, Isozaki Y, Toyoda S, Hasegawa H (2011) Millennial-scale oscillations of the westerly jet path during the last glacial period. J Asian Earth Sci 40:1214-1220

Nagashima K, Tada R, Toyoda S (2013) Westerly jet-East Asian summer monsoon connection during the Holocene. Geochem Geophys Geosyst 14:5041-5053. https://doi.org/10.1002/2013gc004931

Nakagawa T, Tarasov PE, Kitagawa H, Yasuda Y, Gotanda K (2006) Seasonally specific responses of the East Asian monsoon to deglacial climate changes. Geology 34:521-524

Nitani H (1972) On the deep and bottom waters in the Japan Sea. In: Shoji D (ed) Research in hydrography and oceanograph. Hydrographic Department of Japan, pp 151-201

Oba T (1988) Comment for sea level change. The Quaternary Research (DaiyonkiKenkyu) 26:243-250, (in Japanese with English abstract). https://doi.org/10. 4116/jaqua.26.3_243

Oba T, Kato M, Kitazato H, Koizumi I, Omura A, Sakai T, Takayama T (1991) Paleoenvironmental changes in the Japan Sea during the last 85,000 years. Paleoceanography 6:499-518

Okuno M, Nakamura T, Moriwaki H, Kobayashi T (1997) AMS radiocarbon dating of the Sakurajima tephra group, southern Kyushu, Japan. Nucl Instrum Methods Phys Res, Sect B 123:470-474. https://doi.org/10.1016/S0168583X(96)00614-3

Pausata FSR, Battisti DS, Nisancioglu KH, Bitz CM (2011) Chinese stalagmite $\delta^{18} \mathrm{O}$ controlled by changes in the Indian monsoon during a simulated Heinrich event. Nat Geosci 4:474-480. https://doi.org/10.1038/ngeo1169

Reimer PJ, Bard E, Bayliss A, Beck JW, Blackwell PG, Bronk Ramsey C, Buck $\mathrm{CE}$, Cheng $\mathrm{H}$, Edwards RL, Friedrich M, Grootes PM, Guilderson TP, Haflidason H, Hajdas I, Hatté C, Heaton TJ, Hoffmann DL, Hogg AG, Hughen KA, Kaiser KF, Kromer B, Manning SW, Niu M, Reimer RW, Richards DA, Scott EM, Southon JR, Staff RA, Turney CSM, van der Plicht J (2013) IntCal13 and Marine13 radiocarbon age calibration curves 050,000 years cal BP. Radiocarbon 55:1869-1887
Sagawa T, Nagahashi Y, Satoguchi Y, Holbourn A, Itaki T, Gallagher SJ, Saavedra-Pellitero M, Ikehara K, Irino T, Tada R (2018) Integrated tephrostratigraphy and stable isotope stratigraphy in the Japan Sea and East China Sea using IODP sites U1426, U1427, and U1429, expedition 346 Asian monsoon. Prog Earth Planet Sci 5:18. https://doi.org/10.1186/ s40645-018-0168-7

Sampe T, Xie S-P (2010) Large-scale dynamics of the meiyu-baiu rainband: environmental forcing by the westerly jet. J Clim 23:113-134. https://doi.org/ 10.1175/2009jcli3128.1

Siddall M, Rohling EJ, Almogi-Labin A, Hemleben C, Meischner D, Schmelzer I, Smeed DA (2003) Sea-level fluctuations during the last glacial cycle. Nature 423:853-858. https://doi.org/10.1038/nature01690

Smith VC, Staff RA, Blockley SPE, Bronk Ramsey C, Nakagawa T, Mark DF, Takemura K, Danhara T (2013) Identification and correlation of visible tephras in the Lake Suigetsu SG06 sedimentary archive, Japan: chronostratigraphic markers for synchronising of east Asian/West Pacific palaeoclimatic records across the last $150 \mathrm{ka}$. Quat Sci Rev 67:121-137

Stott L, Poulsen C, Lund S, Thunell R (2002) Super ENSO and global climate oscillations at millennial time scales. Science 297:222-226

Stuiver M, Reimer PJ, Reimer RW (2016) CALIB radiocarbon calibration version 7.1. In: calib.qub.ac.uk http://calib.org/calib/. Accessed 1 Apr 2019

Suda K (1932) On the bottom water in the Japan Sea (preliminary report). Kaiyojiho 4:221-240

Sun Y, Clemens SC, Morrill C, Lin X, Wang X, An Z (2012) Influence of Atlantic meridional overturning circulation on the East Asian winter monsoon. Nat Geosci 5:46-49. https://doi.org/10.1038/ngeo1326

Sun Y, Oppo DW, Xiang R, Liu W, Gao S (2005) Last deglaciation in the Okinawa Trough: subtropical Northwest Pacific link to Northern Hemisphere and tropical climate. Paleoceanography 20:PA4005. https://doi.org/10.1029/ 2004pa001061

Svensson A, Andersen KK, Bigler M, Clausen HB, Dahl-Jensen D, Davies SM, Johnsen SJ, Muscheler R, Parrenin F, Rasmussen SO, Röthlisberger R, Seierstad I, Steffensen JP, Vinther BM (2008) A 60,000 year Greenland stratigraphic ice core chronology. Clim Past 4:47-57

Tada R, Irino T, Ikehara K, Karasuda A, Sugisaki S, Xuan C, Sagawa T, Itaki T, Kubota Y, Lu S, Seki A, Murray RW, Alvarez-Zarikian C, Anderson WT, Bassetti M-A, Brace BJ, Clemens SC, da Costa Gurgel MH, Dickens GR, Dunlea AG, Gallagher SJ, Giosan L, Henderson ACG, Holbourn AE, Kinsley CW, Lee GS, Lee KE, Lofi J, Lopes CICD, Saavedra-Pellitero M, Peterson LC, Singh RK, Toucanne S, Wan S, Zheng H, Ziegler M (2018) High-resolution and high-precision correlation of dark and light layers in the Quaternary hemipelagic sediments of the Japan Sea recovered during IODP expedition 346. Prog Earth Planet Sci 5:19. https://doi.org/10.1186/ s40645-018-0167-8

Tada R, Irino T, Koizumi I (1995) Possible Dansgaard-Oeschger oscillation signal recorded in the Japan Sea sediments, Global fluxes of carbon and its related substances in the coastal sea-ocean-atmosphere system, Proceedings of 1994 IGBP symposium, 1995, pp 517-522

Tada R, Irino T, Koizumi I (1999) Land-ocean linkages over orbital and millennial timescales recorded in late Quaternary sediments of the Japan Sea. Paleoceanography 14:236-247

Tanaka A, Yoneda M, Uchida M, Uehiro T, Shibata Y, Morita M (2000) Recent advances in ${ }^{14} \mathrm{C}$ measurement at NIES-TERRA. Nucl Instrum Methods Phys Res, Sect B 172:107-111. https://doi.org/10.1016/S0168-583X(00)00346-3

Thirumalai K, Quinn TM, Marino G (2016) Constraining past seawater $\delta^{18} \mathrm{O}$ and temperature records developed from foraminiferal geochemistry. Paleoceanography 31:1409-1422. https://doi.org/10.1002/2016PA002970

Tierney JE, Pausata FSR, deMenocal P (2015) Deglacial Indian monsoon failure and North Atlantic stadials linked by Indian Ocean surface cooling. Nat Geosci 9:46-50. https://doi.org/10.1038/ngeo2603

Uchida M, Ohkushi K, Kimoto K, Inagaki F, Ishimura T, Tsunogai U, TuZino T, Shibata Y (2008) Radiocarbon-based carbon source quantification of anomalous isotopic foraminifera in last glacial sediments in the western North Pacific. Geochem Geophys Geosyst 9:Q04N14. https://doi.org/10.1029/ 2006 gc001558

Uchida M, Shibata Y, Yoneda M, Kobayashi T, Morita M (2004) Technical progress in AMS microscale radiocarbon analysis. Nucl Instrum Methods Phys Res, Sect B 223-224:313-317. https://doi.org/10.1016/j.nimb.2004.04.062

Udarbe-Walker MJB, Villanoy CL (2001) Structure of potential upwelling areas in the Philippines. Deep-Sea Res I Oceanogr Res Pap 48:1499-1518. https://doi. org/10.1016/S0967-0637(00)00100-X 
Ueda H, Kamae Y, Hayasaki M, Kitoh A, Watanabe S, Miki Y, Kumai A (2015) Combined effects of recent Pacific cooling and Indian Ocean warming on the Asian monsoon. Nat Commun 6:1-8. https://doi.org/10.1038/ ncomms9854

Waelbroeck C, Labeyrie L, Michel E, Duplessy JC, McManus JF, Lambeck K, Balbon E, Labracherie M (2002) Sea-level and deep water temperature changes derived from benthic foraminifera isotopic records. Quat Sci Rev 21:295-305

Wang L, Oba T (1998) Tele-connections between East Asian monsoon and the highlatitude climate. Quat Res 37:211-219. https://doi.org/10.4116/jaqua.37.211

Wang Y, Cheng H, Edwards RL, Kong X, Shao X, Chen S, Wu J, Jiang X, Wang X, An Z (2008) Millennial- and orbital-scale changes in the East Asian monsoon over the past 224,000 years. Nature 451:1090-1093. https://doi.org/10.1038/ nature06692

Wang YJ, Cheng H, Edwards RL, An ZS, Wu JY, Shen CC, Dorale JA (2001) A highresolution absolute-dated late Pleistocene monsoon record from Hulu Cave, China. Science 294:2345-2348. https://doi.org/10.1126/science.1064618

Watanabe S, Tada R, Ikehara K, Fujine K, Kido Y (2007) Sediment fabrics, oxygenation history, and circulation modes of Japan Sea during the Late Quaternary. Palaeogeogr Palaeoclimatol Palaeoecol 247:50-64

Yamasaki M, Murakami T, Tsuchihashi M, Oda M (2010) Seasonal variation in living planktic foraminiferal assemblage in the northeastern part of the East China Sea. Fossils 87:35-46

Yokoyama Y, Esat TM (2011) Global climate and sea level: enduring variability and rapid fluctuations over the past 150,000 years. Oceanography 24:54-69

Yokoyama Y, Kido Y, Tada R, Minami I, Finkel RC, Matsuzaki H (2007) Japan Sea oxygen isotope stratigraphy and global sea-level changes for the last 50,000 years recorded in sediment cores from the Oki Ridge. Palaeogeogr Palaeoclimatol Palaeoecol 247:5-17

Yoneda M, Shibata Y, Tanaka A, Uehiro T, Morita M, Uchida M, Kobayashi T, Kobayashi C, Suzuki R, Miyamoto K, Hancock B, Dibden C, Edmonds JS (2004) AMS ${ }^{14} \mathrm{C}$ measurement and preparative techniques at NIES-TERRA. Nucl Instrum Methods Phys Res, Sect B 223-224:116-123. https://doi.org/10.1016/ j.nimb.2004.04.026

Yoshikawa S (1976) The volcanic ash layers of the Osaka Group. J Geol Soc Jpn 82:497-515

Zhang H, Griffiths ML, Chiang JCH, Kong W, Wu S, Atwood A, Huang J, Cheng H, Ning Y, Xie S (2018) East Asian hydroclimate modulated by the position of the westerlies during termination I. Science 362:580-583. https://doi.org/10. $1126 /$ science.aat9393

Zhang R, Delworth TL (2005) Simulated tropical response to a substantial weakening of the Atlantic thermohaline circulation. J Clim 18:1853-1860

\section{Submit your manuscript to a SpringerOpen ${ }^{\circ}$ journal and benefit from:}

- Convenient online submission

- Rigorous peer review

- Open access: articles freely available online

High visibility within the field

- Retaining the copyright to your article

Submit your next manuscript at $\boldsymbol{\nabla}$ springeropen.com 